\title{
EVALUATION ON THE USE OF CERIUM IN THE NBL TITRIMETRIC METHOD
}

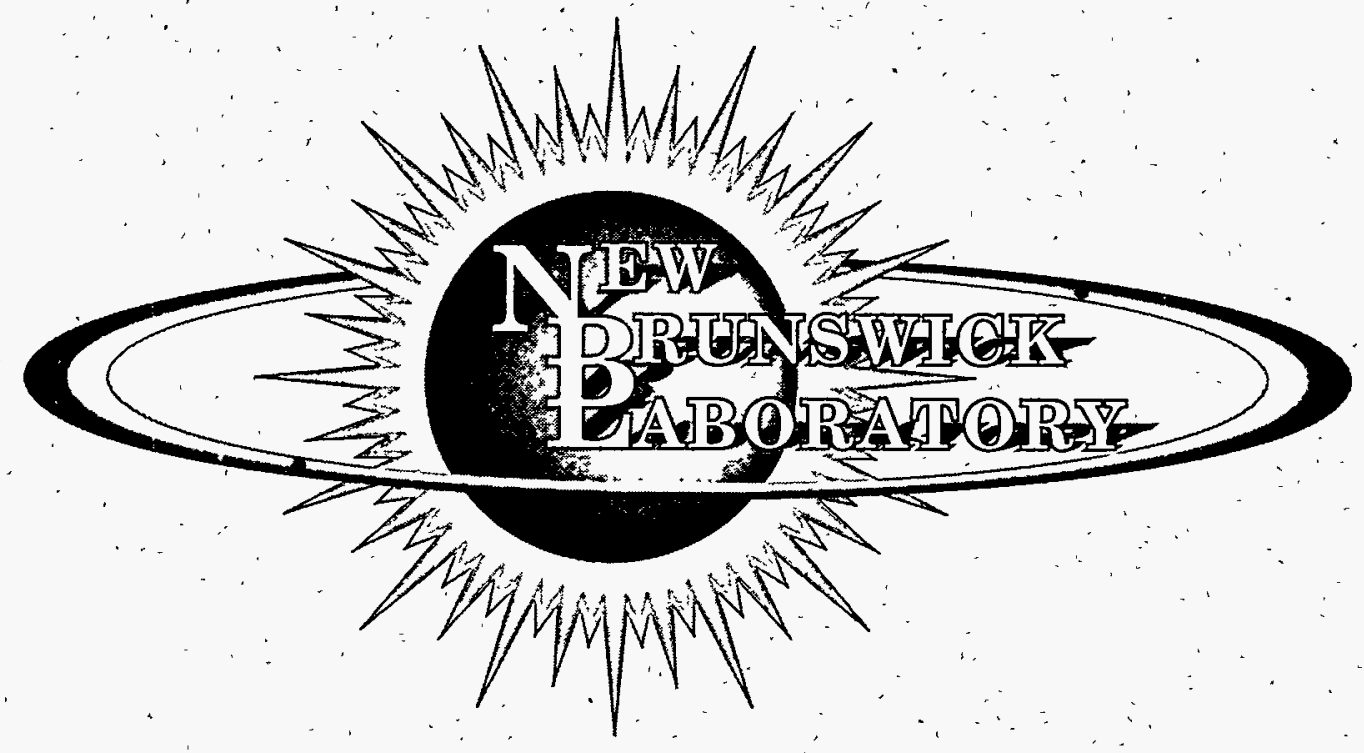

Jeffrey P. Zebrowski, Glennda J. Orlowicz, Kimberly D. Johnson, Marianne M. Smith and Michael D. Soriano

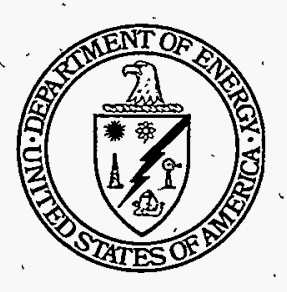


NBL-332

\section{U.S. DEPARTMENT OF ENERGY}

\section{EVALUATION ON THE USE OF CERIUM IN THE NBL TITRIMETRIC METHOD}

Jeffrey P. Zebrowski, Glennda J. Orlowicz, Kimberly D. Johnson, Marianne M. Smith and Michael D. Soriano

Research and Development Report

NEW BRUNSWICK LABORATORY

Argonne, Illinois

March, 1995

H. Rodney Martin, Acting Director

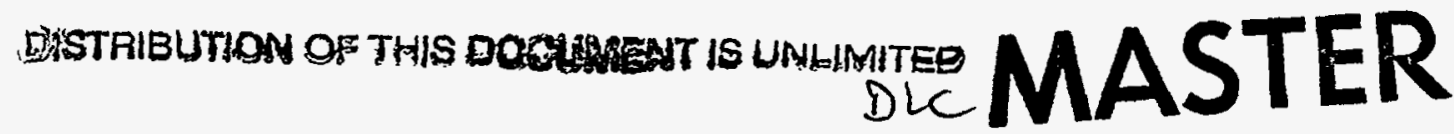




\section{DISCLAIMER}

Portions of this document may be illegible in electronic image products. Images are produced from the best available original document. 
NOTICE

REFERENCE TO A PARTICULAR BRAND OR MANUFACTURER OF EQUIPMENT DOES NOT CONSTITUTE AN ENDORSEMENT BY THE NEW BRUNSWICK LABORATORY OR THE DEPARTMENT OF ENERGY. 
INTRODUCTION $\ldots \ldots \ldots \ldots \ldots \ldots \ldots \ldots \ldots \ldots \ldots \ldots \ldots \ldots \ldots \ldots \ldots \ldots \ldots$

EXPERIMENTAL $\ldots \ldots \ldots \ldots \ldots \ldots \ldots \ldots \ldots \ldots \ldots \ldots \ldots \ldots \ldots \ldots \ldots \ldots \ldots \ldots$

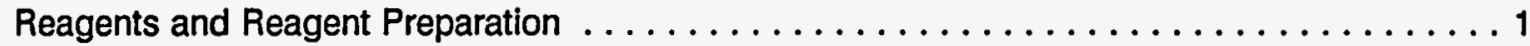

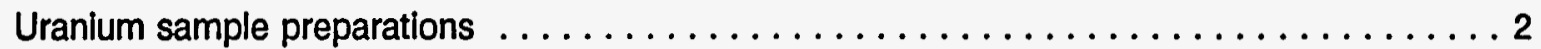

Preparation of $0.027 \mathrm{~N}$ Cerium (IV) Titrant in $1.0 \mathrm{M} \mathrm{H}_{2} \mathrm{SO}_{4} \ldots \ldots \ldots \ldots \ldots \ldots \ldots$

The NBL Titrimetric Method of Uranium Analysis $\ldots \ldots \ldots \ldots \ldots \ldots \ldots \ldots \ldots$

ASSAY OF PURE URANIUM SAMPLES $\ldots \ldots \ldots \ldots \ldots \ldots \ldots \ldots \ldots \ldots \ldots \ldots \ldots$

Statistical Plan of Analyses for Assay of Pure Uranium Samples $\ldots \ldots \ldots \ldots \ldots \ldots \ldots$

Table 1 Titration Schedule for Analysis of Pure Uranium Samples $\ldots \ldots \ldots \ldots \ldots \ldots \ldots$

Table 2 Titration Schedule for Auxiliary Plan for the

Analysis of Pure Uranium . . . . . . . . . . . . . . . . . . 5

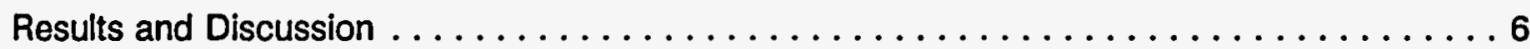

Figure 1 Comparison of Titration Curves $\ldots \ldots \ldots \ldots \ldots \ldots \ldots \ldots \ldots \ldots \ldots$

Table 3 Comparison of Results of Samples Titrated with Cerium and Potassium Dichromate Solutions . . . . . . . . . . . . . . . 9

Table 4 Comparison of Results of Samples Titrated with Cerium and Potassium Dichromate Solutions by Analyst . . . . . . . . . . . . 9

Table 5 Comparison of Results of Samples Titrated with Cerium and Potassium Dichromate Solutions for Days 3 and $4 \ldots \ldots \ldots \ldots \ldots$

Table 6 Comparison of Results of Samples Titrated with Cerium and Potassium Dichromate Solutions by Analyst for

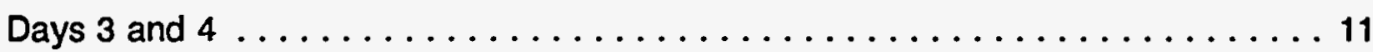

Table 7 Descriptive Statistics for Cerium Titrations $\ldots \ldots \ldots \ldots \ldots \ldots \ldots \ldots \ldots \ldots \ldots$

Table 8 Analysis of Relative Difference Data . . . . . . . . . . . . . . . . . 14

Table 9 Comparison of Potassium Dichromate and Cerium Titrant Precisions . . . . . . . . . . . . . . . . . . . . . . . . . . 14

Figure 2 Auxiliary Statistical Plan Results Excluding Outliers $\ldots \ldots \ldots \ldots \ldots \ldots \ldots$

EFFECTS OF IMPURITIES ON THE CERIC TITRATION METHOD $\ldots \ldots \ldots \ldots \ldots \ldots \ldots \ldots$

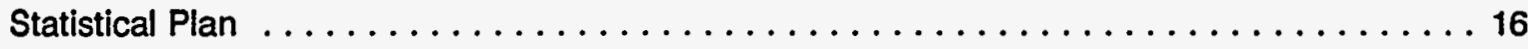

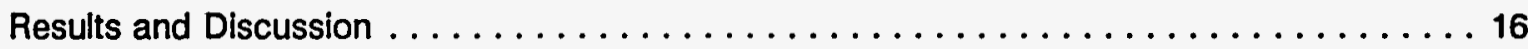



Table 10 Titration Schedule for Analysis of Uranium Samples with Added Impurities . . . . 17

Table 11 Effects of Various Impurities on Ceric Titrations $\ldots \ldots \ldots \ldots \ldots \ldots \ldots \ldots$

STABILITY OF CERIC AMMONIUM NITRATE IN $1 M^{\mathrm{H}_{2}} \mathrm{SO}_{4} \ldots \ldots \ldots \ldots \ldots \ldots \ldots \ldots \ldots$

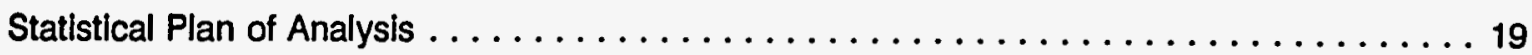

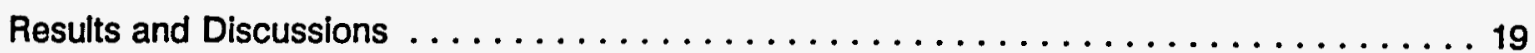

Figure 3 Ceric Titration Results as a Function of Time, Analyst $1 \ldots \ldots \ldots \ldots \ldots \ldots$

Figure 4 Ceric Titration Results as a Function of Time, Analyst $2 \ldots \ldots \ldots \ldots \ldots \ldots 22$

Table 12 Mean \%RD and Standard Deviation Results Based on

Standardization Using First Three Days Results . . . . . . . . . . . . 23

Table 13 Mean \%RD and Standard Deviation Results Based on

Standardization Using First Five Days Results . . . . . . . . . . . . 23

Table 14 Results of Regression Analysis for Three Day and

Five Day Standardization . . . . . . . . . . . . . . . . . 24

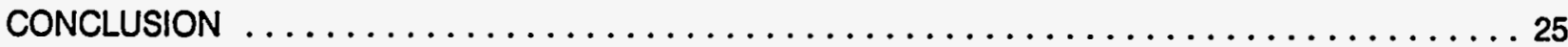

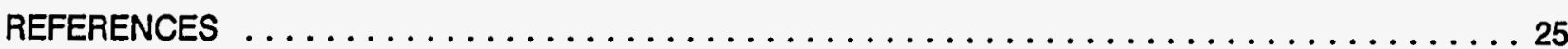

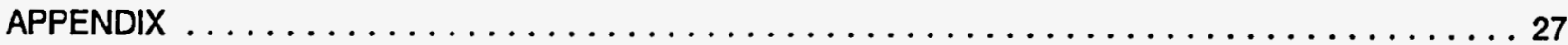

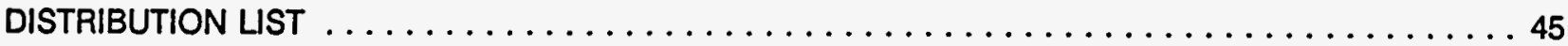





\section{ACKNOWLEDGMENTS}

This work was performed under the auspices of the Office of Safeguards and Security, in the Office of NonProliferation and National Security. Funding for this work was provided by EM-334, Waste Minimization in the Office of Waste Management.

The authors express their appreciation to R. D. Oldham, U. I. Narayanan and L. D. Preston for providing technical guidance, to Eric Dallmann for providing assistance with waste categorization, to W. G. Mitchell and M. I. Spaletto for reviewing this report, and to M. Ficner for secretarial support. 
. 


\section{ABSTRACT}

An alternative to the use of potassium dichromate as a titrant in the New Brunswick Laboratory (NBL) Titrimetric Method for uranium analysis was sought since the presence of chromium in the resultant waste makes disposal of the waste difficult. Substitution of a ceric-based titrant for the potassium dichromate titrant normally used in the method was statistically evaluated. Analysis of the data indicated statistically equivalent precisions for the two methods, but a significant overall bias of $+0.035 \%$ for the ceric titrant procedure. The cause of the bias was investigated, alterations to the procedure were made, and a second statistical study was performed. This second study revealed no statistically significant bias, nor any analystto-analyst variation in the ceric titration procedure. A statistically significant day-to-day variation was detected, but this was physically small $(0.015 \%)$ and was only detected because of the within-day precision of the method. The added mean and standard deviation of the \%RD for a single measurement was found to be $0.031 \%$. A comparison with quality control blind dichromate titration data again indicated that the overall precision of the two methods is similar.

The effects of ten elements on the ceric titration's performance was determined. Ten impurities were chosen for the study: $\mathrm{Co}, \mathrm{Tl}, \mathrm{Cu}, \mathrm{Ni}, \mathrm{Na}, \mathrm{Mg}, \mathrm{Gd}, \mathrm{Zn}, \mathrm{Cd}$, and $\mathrm{Cr}$. In previous work at NBL these impurities were found not to cause any interference problems when using the potassium dichromate titrant. This study indicated similar results for the ceric titrant, with the exception of $\mathrm{TI}$. All the elements (excluding $\mathrm{Ti}$ and $\mathrm{Cr}$ ), caused no statistically significant bias in uranium measurements at levels of $10 \mathrm{mg}$ impurity per $20-40 \mathrm{mg}$ uranium. The presence of Ti was found to cause a bias of $-0.05 \%$. This has been attributed to the presence of sulfate lons, resulting in the precipitation of titanium sulfate and the occlusion of uranium. A negative bias of $0.012 \%$ was also statistically observed in the samples containing chromium impurities.

An indication of the stability of the ceric ammonium nitrate titrant (stabilized in $1 \mathrm{M} \mathrm{H}_{2} \mathrm{SO}_{4}$ ) used in these studies was statistically determined. As prepared and stored, a decrease of $0.01 \%$ per month in the titrant factor was observed. 


\section{INTRODUCTION}

The NBL-Modified Davies and Gray Titrimetric Method (commonly called the NBL Titrimetric Method) is a standard method of uranium analysis. The NBL Titrimetric Method has previously been demonstrated to be a very accurate and rugged method, ${ }^{1}$ capable of handling many sample types without bias. ${ }^{2}$ In this procedure, all uranium present is reduced to $U(I V)$ and is titrated with potassium dichromate to $U(V)$. The waste generated by this procedure is corrosive by RCRA standards $(\mathrm{pH} \leq 2.0)$ but it can be neutralized at the time of generation. However, hexavalent chromium compounds are toxic and known human carcinogens; thus, the waste generated contains chromium at high enough concentrations for classification of the waste as a mixed waste, even after neutralization. It is becoming extremely difficult, within the current regulatory environment, for NBL to dispose of the waste materials generated by the numerous titrations performed within the laboratory.

Since the NBL Titrimetric Method is commonly used throughout the DOE complex, the waste disposal problem is not unique to NBL. No DOE facility presently has the means to treat or dispose of waste of this type. NBL has therefore sought an alternative procedure which has a precision and bias comparable to the NBL Titrimetric Method. The literature was reviewed to determine if any viable option was available. No method of uranium analysis could be found that meets NBL's requirements for precision, accuracy, ease of use, and insensitivity to impurities. However, if the dichromate required by the NBL titrimetric method could be replaced with another titrant, the waste solutions would not contain RCRA-listed chemicals. Without the dichromate, the waste could be neutralized and more easily disposed of as radioactive waste. It was concluded, therefore, that the prime method for further study was the NBL Titrimetric Method in which the potassium dichromate titrant was replaced by a cerium(IV)-based titrant.

In order to qualify the substitution of a cerium(IV) titrant into the NBL Titrimetric Method, the following three elements of the method were investigated: 1) the method's ability to handle pure uranium samples, 2) the impact the presence of impurities has on the method's performance, and 3) the stability of the cerium(IV)based titrant. All three factors were tested and statistically evaluated. The results of these investigations are reported herein.

\section{EXPERIMENTAL}

\section{$\underline{\text { Reagents and Reagent Preparation }}$}

The ferrous sulfate, $85 \%$ phosphoric acid, nitric acid, and sulfuric acid were all obtained from Mallinckrodt, and the sulfamic acid was purchased from Eastman fine chemicals. The vanadium oxysulfate hydrate was acquired from Noah Technologies Corporation. The ceric ammonium nitrate was acquired form the 
G. Frederick Smith Chemical Company. The potassium dichromate used in the experiments was either NIST Standard Reference Material (SRM) 136 or NBL Certified Reference Material (CRM) 99. Custom grade standard solutions (with a nominal concentration of $1000 \mu \mathrm{g} / \mathrm{mL}$ ) for use as metal impurities were obtained for the following elements from Inorganic Ventures: $\mathrm{Cu}, \mathrm{Ti}, \mathrm{Co}, \mathrm{Ni}, \mathrm{Na}, \mathrm{Mg}, \mathrm{Gd}, \mathrm{Zn}, \mathrm{Cd}$, and $\mathrm{Cr}$.

Each lot of phosphoric acid had to pass a lab acceptance procedure before the lot could be used. Additionally, to each $2.2 \mathrm{~L}$ bottle of phosphoric acid either approximately 8 drops of $6 \%$ potassium dichromate or 35 drops of $0.4 \mathrm{~N}$ ceric ammonium nitrate in $1 M$ sulfuric acid were added, depending on whether the acid was to be used for ceric or dichromate titrations.

The nitric acid oxidizing reagent used in the titrations was prepared by dissolving $1.0 \mathrm{~g}$ ammonium molybdate, $\left[\left(\mathrm{NH}_{4}\right)_{6} \mathrm{Mo}_{7} \mathrm{O}_{24} \cdot 4 \mathrm{H}_{2} \mathrm{O}\right]$, in $100 \mathrm{~mL}$ of distilled water. To this solution, $125 \mathrm{~mL}$ of concentrated nitric acid and $25 \mathrm{~mL}$ of $1.5 \mathrm{M}$ sulfamic acid were added, and the solution was allowed to cool.

The platinum electrodes were cleaned daily by flaming to a white heat and quenching in concentrated nitric acid.

\section{Uranium sample preparations}

All uranium samples and standards were prepared from New Brunswick Laboratory CRM 112-A, Uranium Metal Assay Standard. The uranium metal standard pieces, after being dissolved in nitric acid (with a small amount of sulfuric acid added to speed dissolution), were diluted in water, aliquanted into $400 \mathrm{~mL}$ beakers, and brought to dryness on a steam bath. With knowledge of the masses of the uranium metal pieces, the diluted uranium solution, and the individual aliquants, the mass of uranium in each aliquant was determined. Sample sizes ranged from $20-45 \mathrm{mg} \mathrm{U}$.

Uranium samples for use in the impurities study were prepared as described above. The uranium samples were then spiked with $10 \mathrm{~mL}$ of standard metal solutions, resulting in a total of $10 \mathrm{mg}$ of impurities per sample, and brought to dryness on a steam bath. Each sample contained only one impurity.

\section{Preparation of $0.027 \mathrm{~N}$ Cerium (IV) Titrant in $1.0 \mathrm{M} \mathrm{H}_{2} \mathrm{SO}_{4}$}

To approximately $8 \mathrm{~L}$ of distilled water, $560 \mathrm{~mL}$ of concentrated sulfuric acid were carefully added. This was allowed to cool to room temperature and diluted to $10 \mathrm{l}$. To this was added $148 \mathrm{~g}$ of ammonium ceric nitrate. The solution was well mixed so as to assure that all the ceric salt was dissolved. The titrant was then set aside for one month to allow settling of a fine sediment and the titrant solution was then decanted off and filtered into a separate $10 \mathrm{~L}$ bottle. The resultant solution was again mixed to assure homogeneity before being divided into 4 separate bottles for distribution to analysts. 
Both the ceric and dichromate titrants used in the studies were standardized against weight aliquants of standard uranium solutions prepared from CRM 112-A. The resulting factor was calculated in terms of $\mathrm{mg}$ uranium per gram of titrant. The ceric titrant preparation described above gives a titrant factor similar to the factor of typical dichromate titrant solutions used at NBL.

The NBL Titrimetric Method of Uranium Analysis

For ceric and dichromate titrations, the typical titration procedure is as follows: The sample aliquant is dissolved in 12-15 mL of water. To this is added $40 \mathrm{~mL}$ concentrated phosphoric acid. The sample is stirred with a Teflon coated magnetic stir bar, and the following reagents are added: $5 \mathrm{~mL}$ of $1.5 \mathrm{M}$ sulfamic acid, $5 \mathrm{~mL}$ of $1 M$ ferrous sulfate, and after a 30 second wait, $10 \mathrm{~mL}$ of the nitric acid oxidizing reagent. After the solution becomes clear, a three minute interval is required before $10 \mathrm{~mL}$ of $0.075 \%$ vanadyl sulfate in $1 \%$ sulfuric acid is added, followed immediately by the addition of the titrant. A Pt indicator electrode and a calomel reference electrode are used, and the solution is titrated to a potential of $590 \mathrm{mV}$. All titrations used mass measurements of the titrant for greater accuracy and precision.

Titration blanks, consisting of all reagents but with no uranium present, were run prior to sample titrations. The mass of the titrant used during the blank was subtracted from all subsequent sample titrations. Separate blank values were determined for the ceric and dichromate titrants, and once determined, the blank value was used for all titrations performed that day.

\section{ASSAY OF PURE URANIUM SAMPLES}

\section{Statistical Plan of Analyses for Assay of Pure Uranium Samples}

A plan of analysis was prepared for the statistical analysis of the NBL Titrimetric Method using $\mathrm{Ce}(\mathrm{IV})$ as the titrant. The statistical plan allowed for a determination of precision and bias in the method. Additionally, a direct comparison of the accuracy and precision of the ceric and dichromate methods was possible since samples were titrated using both titrants.

The statistical plan called for three analysts (designated Analyst A, B and C) titrating for four days each. 150 sample aliquants, prepared from the same master solution, were weighed. Each analyst was assigned 40 aliquants for analysis, and an additional 10 for use as spares (for overtitrations, or samples otherwise determined to be questionable). The amount of uranium within each sample was blinded to the analysts. Table 1 shows the titration schedule followed by all three analysts in the study. The assignment of the samples and spares, as well as their order within the titration schedule, was determined by a random 


\begin{tabular}{|c|c|c|c|}
\hline \multicolumn{4}{|c|}{$\begin{array}{c}\text { Table } 1 \\
\text { Titration Schedule for Analysis of Pure Uranium Samples }\end{array}$} \\
\hline Day 1 & Day 2 & Day 3 & Day 4 \\
\hline Known (KD) & Known (KD) & Known (KD) & Known (KD) \\
\hline QC Blind (KD) & QC Blind (KD) & $Q C$ Blind (KD) & QC Blind (KD) \\
\hline Known (Ce) & Known (Ce) & Known (Ce) & Known (Ce) \\
\hline Sample (Ce) & Sample (Ce) & Sample (Ce) & Sample (Ce) \\
\hline Sample (Ce) & Sample (KD) & Sample (Ce) & Sample (KD) \\
\hline Sample (Ce) & Sample (Ce) & Sample (Ce) & Sample (Ce) \\
\hline Sample (KD) & Sample (KD) & Sample (KD) & Sample (KD) \\
\hline Sample (KD) & Sample (Ce) & Sample (KD) & Sample (Ce) \\
\hline QC Blind (KD) & QC Blind (KD) & QC Blind (KD) & QC Blind (KD) \\
\hline Sample (Ce) & Sample (Ce) & Sample (Ce) & Sample (Ce) \\
\hline Sample (KD) & Sample (Ce) & Sample (KD) & Sample (Ce) \\
\hline Sample (Ce) & Sample (Ce) & Sample (Ce) & Sample (Ce) \\
\hline Sample (KD) & Sample (KD) & Sample (KD) & Sample (KD) \\
\hline Sample (Ce) & Sample (KD) & Sample (Ce) & Sample (Ce) \\
\hline QC Blind (KD) & QC Blind (KD) & QC Blind (KD) & QC Blind (KD) \\
\hline $\begin{array}{l}\mathrm{KD}=\text { pota } \\
\mathrm{Ce}=\text { ceric }\end{array}$ & $\begin{array}{l}\text { hromate titrant } \\
\text { ed }\end{array}$ & & \\
\hline
\end{tabular}

number generator. Initial sample knowns were titrated with dichromate and ceric titrants to give the individual analyst an indication that the systems were working properly prior to starting the day's titrations, while the QC blind titrations were performed to both confirm that the system remained in control and also to detect biases. In addition to the four days of titration for each analyst within the study, one day was required for the standardization of the ceric titrant. Standardization was performed following NBL procedure which involved titrating two sets of five samples each from previously prepared and verified uranium standard solutions.

Due to some problems with the experimental procedure that were noted during the first study, and which impacted on the results of the statistical evaluation, an auxiliary plan of analysis was developed. The observed problems are discussed in more detail in the following section. No direct comparison of the ceric 
titrant with the potassium dichromate titrant was done in the auxiliary study. Two analysts (designated Analyst 1 and Analyst 2) titrated eight samples a day for five days, with the first day of titration (designated as Day 0) used to standardize the ceric titrant. All uranium samples, including the samples used for titrant standardization, were prepared from the same master solution, and were randomly distributed to the two analysts. The actual uranium sample amount was blinded to the analysts. An opening titration using the dichromate titrant was performed as an indication to the analyst that the system was under control. Additionally, opening and closing blinded dichromate titrations were performed mainly as QC system checks, and were not used to correct for any bias. The titration schedule followed by the two analysts is presented in Table 2. All titrations were completed by the 10th day after standardization of the titrant so as to minimize any effects of possible titrant instability.

\begin{tabular}{|c|c|c|c|c|}
\hline \multicolumn{5}{|c|}{ Titration Schedule for Auxillary Plan for the Analysis of Pure Uranium } \\
\hline $\begin{array}{l}\text { Day } 0 \\
\text { Standardization }\end{array}$ & $\begin{array}{c}\text { Day: } 1 \\
\vdots \cdots\end{array}$ & Day 2 & . Day 3 & $\because$ : Day 4 \\
\hline Tuesday & Thursday & Tuesday & Thursday & Friday \\
\hline Known (KD) & Known (KD) & Known (KD) & Known (KD) & Known (KD) \\
\hline QC Blind (KD) & QC Blind (KD) & QC Blind (KD) & QC Blind (KD) & QC Blind (KD) \\
\hline Known (Ce) & Known (Ce) & Known (Ce) & Known (Ce) & Known (Ce) \\
\hline Sample (Ce) & Sample (Ce) & Sample (Ce) & Sample (Ce) & Sample (Ce) \\
\hline Sample (Ce) & Sample (Ce) & Sample (Ce) & Sample (Ce) & Sample (Ce) \\
\hline Sample (Ce) & Sample (Ce) & Sample $(\mathrm{Ce})$ & Sample (Ce) & Sample (Ce) \\
\hline Sample (Ce) & Sample (Ce) & Sample (Ce) & Sample (Ce) & Sample (Ce) \\
\hline Sample (Ce) & Sample (Ce) & Sample (Ce) & Sample (Ce) & Sample (Ce) \\
\hline Sample (Ce) & Sample (Ce) & Sample (Ce) & Sample (Ce) & Sample (Ce) \\
\hline Sample (Ce) & Sample (Ce) & Sample (Ce) & Sample (Ce) & Sample (Ce) \\
\hline Sample (Ce) & Sample (Ce) & Sample (Ce) & Sample (Ce) & Sample (Ce) \\
\hline QC Blind (KD) & QC Blind (KD) & QC Blind (KD) & QC Blind (KD) & QC Blind (KD) \\
\hline
\end{tabular}


In the search for a replacement for the potassium dichromate used in the NBL Titrimetric Method of uranium analysis, a decision was made to focus on $\mathrm{Ce}$ (IV)-based titrants, since $\mathrm{Ce}$ (IV) is a well known oxidant and is commonly used for titrations. More importantly, use of a ceric titrant would make the waste produced by the procedure more readily disposable. The $\mathrm{Ce}(\mathrm{IV})$ titrant used in this investigation was prepared from $\left(\mathrm{NH}_{4}\right)_{2} \mathrm{Ce}\left(\mathrm{NO}_{3}\right)_{6}$, since this reagent can be obtained in high purity, and was stabilized in a $1 \mathrm{M}$ sulfuric acid medium in order to prevent the precipitation of hydrous ceric oxide. ${ }^{3}$ The prepared solutions were allowed to sit for one month to allow a minor insoluble solid to settle out. The titrant solutions were then drawn off (so as not to disturb the sediment) and filtered into a second bottle. It should be noted that after the initial precipitation, no additional residue was detected in ceric titrant bottles.

The NBL Titrimetric Method, as developed from the original Davies and Gray titration, ${ }^{4}$ has been extensively investigated and is fairly well understood. The titration is done in a phosphoric acid medium since the formation of the $\mathrm{U}\left(\mathrm{PO}_{4}\right)_{2}{ }^{2-}$ ion stabilizes and prevents oxidation of $\mathrm{U}(\mathrm{IV})$ during the pretitration reactions. Sulfamic acid is added to destroy nitrous oxide which would otherwise catalyze the oxidation of $\mathrm{Fe}(\mathrm{II})$ and $U$ (IV) both in the strong phosphoric acid medium and in the final diluted solution. Ferrous sulfate is then added to reduce $U(V I)$ to $U(I V)$. This reduction requires a high concentration of phosphoric acid to go to completion. The excess $\mathrm{Fe}$ (II) is selectively oxidized to Fe(III) by addition of the nitric acid oxidizing agent containing a Mo(VI) catalytic reagent. This is a complicated reaction; the solution turns dark brown indicating the formation of a nitroso-iron compound, then to a light green with $\mathrm{N}_{2}$ gas evolution. The sample solution is then diluted with a vandyl sulfate solution just prior to the titration with the $\mathrm{Cr}(\mathrm{VI})$ titrant. The vanadyl sulfate solution was found to improve the rate of the oxidation of $U(I V)$ to $U(V I)$.

The NBL titrimetric method is rugged, meaning it has a failfy high tolerance for variations in the experimental conditions. Typically, differences of up to $10 \%$ on the reagent additions lead to no significant variation from sample to sample. Additionally, the effects of impurities have been well studied. ${ }^{5}$ The method is insensitive to most metal impurities, and many impurities that clo cause biases can be eliminated by sample pretreatment. ${ }^{6}$ For example, the bias caused by the presence of $\mathrm{Sb}$ (III) or As(III) can be readily eliminated by oxidation with potassium dichromate at the phosphoric acid addition step. Only a few elements cause enough problems with the titration to require that they be separated from the uranium. These characteristics of the method are very desirable, and were the main reasons for wanting to maintain the basic procedure; thus, use of the ceric titrant in this method was studied.

Early in the analytical work it was found that once a platinum indicator electrode was used for a ceric titration it could not be used for potassium dichromate work. Electrode behavior was sluggish and erratic during dichromate titrations after a ceric titration. Only by repeated fusing of the platinum electrode followed 
by a long conditioning period could the electrode be used again for dichromate titrations. Thus, electrodes were specifically dedicated to ceric or dichromate titrations.

While the potassium dichromate is in a pure aqueous medium, the ceric solution, as indicated previously, is stabilized in $1 M$ sulfuric acid. The presence of the sulfuric acid in the titrant was not expected to produce any bias in the results, since it has been previously found that sulfuric acid produces a bias only if present before the titration reaction. ${ }^{7}$ The major source of concern was that the greater oxidizing potential of the $\mathrm{Ce}^{4+}$ relative to the $\mathrm{Cr}^{6+}$ would cause significant positive bias due to the oxidation of other species present in the solution.

Titration curves (Figure 1) for the method were derived employing both potassium dichromate and the ceric titrants were derived to see how the change in titrant affected the endpoint. Essentially no change in the titration curve was observed upon switching to the ceric titrant and titration to an endpoint of $590 \mathrm{mV}$ vs. SCE was determined to be appropriate for both the ceric and dichromate titration methods.

A preliminary set of titrations of pure uranium samples with the ceric titrant were performed to give an initial indication of the precision of the method, and to uncover any obvious problems with the titrant. Ten acceptable titrations were performed on sample sizes ranging from 20 to $33 \mathrm{mg}$ uranium following the NBL titrimetric procedure with the exception that the $\mathrm{Ce}^{4+}$ titrant replaced the dichromate solution. A standardized titrant factor ( $\mathrm{mg} \mathrm{U} / \mathrm{g}$ titrant) was then calculated. The mean factor (in units of $\mathrm{mg} \mathrm{U} / \mathrm{g}$ titrant) was 2.93183 with a range of 2.93081 to 2.93278 , with a relative standard deviation (RSD) $0.023 \%$, well within the comparable laboratory limits for the dichromate solution. No unusual behavior was observed in these and other preliminary titrations.

To obtain a more quantitative determination of the effects that substituting a ceric titrant for potassium dichromate has on the NBL titrimetric method, a statistical plan that allowed for a direct comparison of the accuracy and precision of the dichromate and the cerium (IV) titration procedures on pure uranium samples was devised. Three sets of data were generated by three analysts (designated analysts $A, B$, and $C$ ) titrating "blind" uranium samples with ceric and potassium dichromate solutions. Known and quality control (QC) blind samples were titrated as controls according to the plan of analysis. The plan of analysis required each analyst to determine a titrant factor using ten known standard aliquants five aliquants taken from each of two separately prepared uranium solutions). This was followed by four days of titrations with three QCs, six cerium titrations, and four potassium dichromate titrations each day. All the uranium samples were prepared from the same master uranium solution with the exception of the QC samples and the known samples used to determine the titrant factors. 


\section{Dichromate Titration Curve}

mass titrant vs. potential

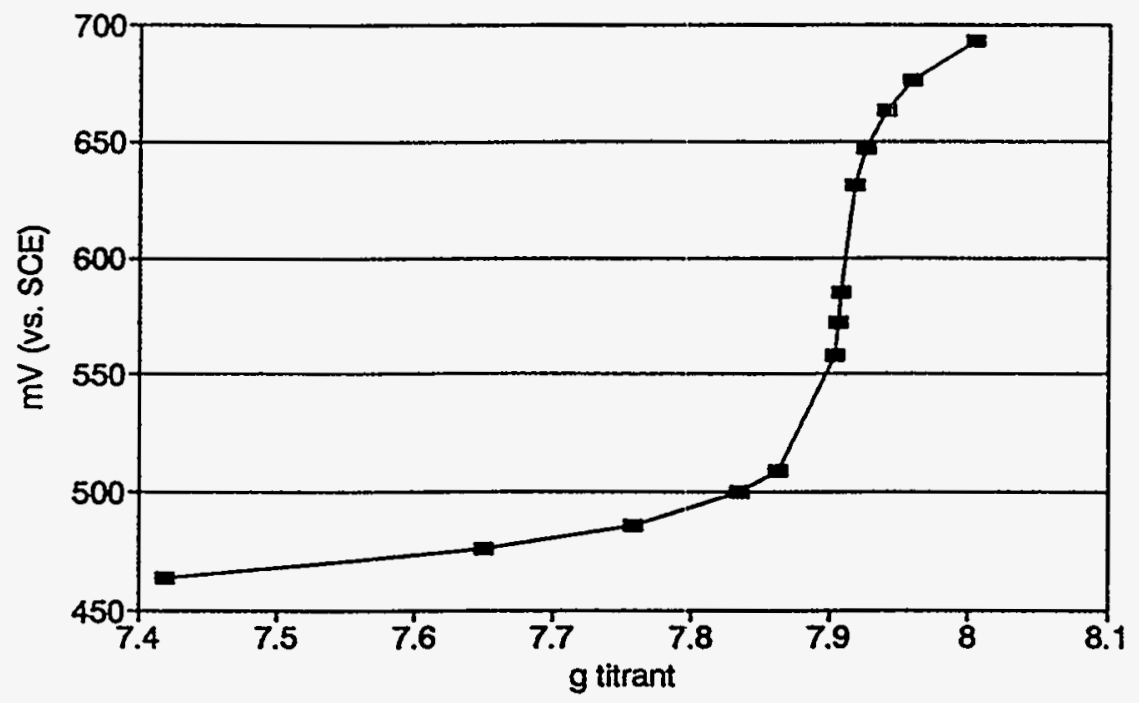

Ceric Titration Curve mass titrant vs. potential

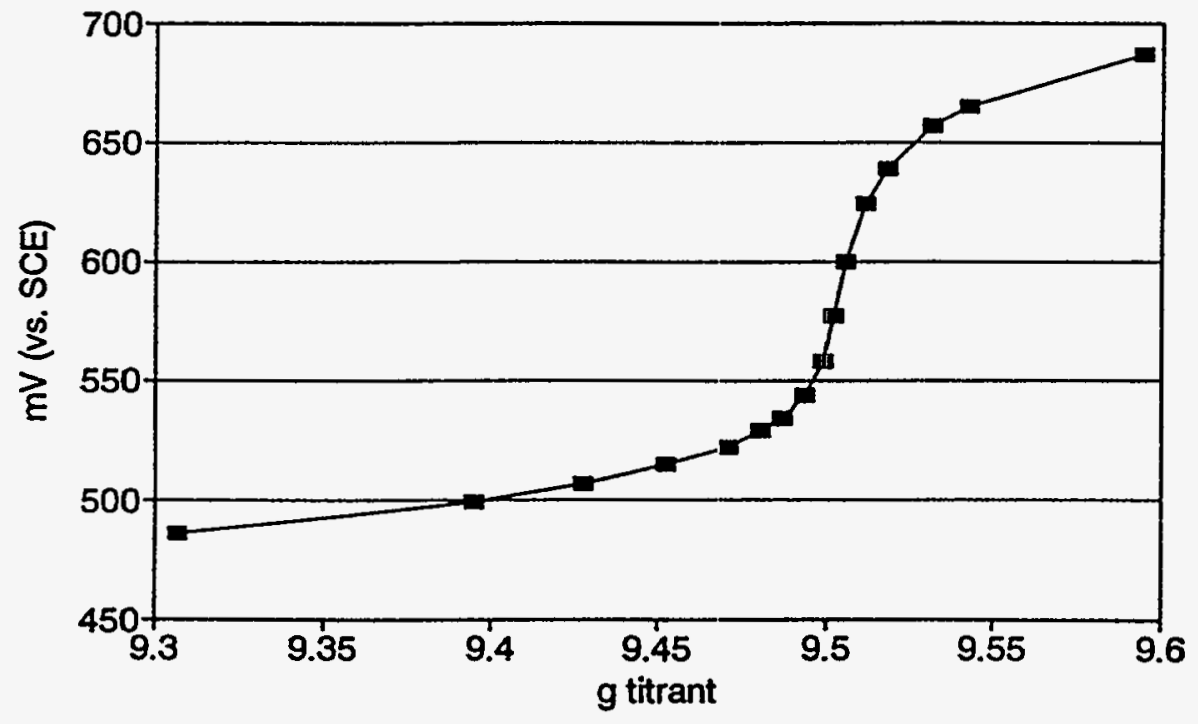

Figure 1. Comparison of Titration Curves 
The data from analysts $A$ and $C$ contained no outliers and very few over-titrations requiring the use of spare replacements. Analyst $A$ had two over-titrations replaced by spares to complete the 40 sample titrations, and analyst $C$ had three overtitrations replaced by spares. These two analysts each submitted the required titrations: 12 QCs, 24 cerium titrations, and 16 potassium dichromate titrations. The data submitted by analyst $B$ had to be eliminated from the data set.

The data contained several outliers, many out-of-control QC titrations (some of which were repeated), and more that one-fourth of the original data were overtitrations. Also, the analyst's control limits exceeded the laboratory limits required for reportable measurements and the samples were titrated over five days rather than the four days prescribed in the plan.

The results of the data produced by Analysts $A$ and $C$ are presented in Tables 3 and 4. Table 3 gives the mean of the percent relative difference (\%RD), standard deviations of the \%RDs, and the $95 \%$ confidence intervals (C.I.) of the mean \%RDs for the ceric and dichromate titrations (excluding the quality control titrations). This is broken down by analyst in Table 4. Results of the analyses indicated a significant overall bias of $+0.035 \%$ by the Ce titration procedure. The cerium titrations also exhibited significant day-to-day $(F=2.85, d f=3, p=0.0480)$ and analyst-to-analyst differences.

\begin{tabular}{|c|c|c|c|c|}
\hline \multicolumn{5}{|c|}{ Comparison of Results of Samples thitrated with centum and Potassium Dichromate Solutions } \\
\hline Titrant & $n$ & Mean $\% \mathrm{RD}$ & Std Dev. & $95 \%$ C. I. \\
\hline Cerium & 48 & 0.035 & 0.025 & 0.0073 \\
\hline $\mathrm{K}_{2} \mathrm{Cr}_{2} \mathrm{O}_{7}$ & 32 & 0.017 & 0.032 & 0.0116 \\
\hline
\end{tabular}

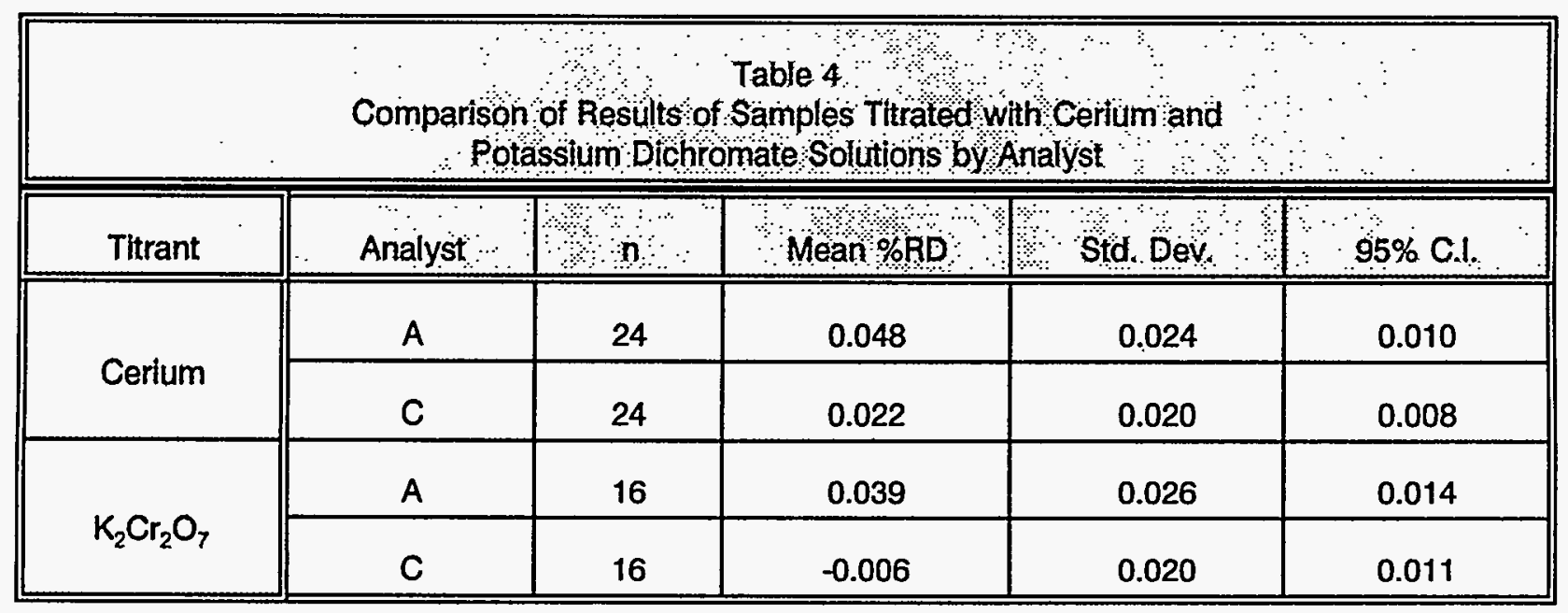


Analyst $A$ showed no significant differences in the \%RDs obtained using the cerium and potassium dichromate titrants. However, the differences in the \%RDs between the cerium and potassium dichromate titrants for Analyst $C$ are highly significant $(F=19.64, d f=1, p<0.0001)$. The lack of significant difference for Analyst $A$ may be due primarily to a questionable dichromate titrant factor. Analyst $C$ completed all titrations within a very short period of time ( 8 calendar days). Analyst $A$ completed the cerium standardization and the first two days of the scheduled titrations within 5 days. The last two days were completed four months later. This required restandardization of both titrants before completion of the final two days of the statistical study. In the intervening period there were indications that the potassium dichromate solution used by Analyst $A$ had some problems associated with it. The results of blind QC controls showed a trend of an increasing positive bias (as if the titrant were losing its oxidizing power). The use of newly recalculated potassium dichromate factors, however, produced unbiased results. This suggested that the positive bias observed for the dichromate titrations by Analyst A was abnormally high (most of the bias seen here is due to the first two days of titrations). Further evidence for bias in the first two days of the study was observed in the data from the QC blind controls titrated by Analyst $A$ during this study. The first two days showed a mean \%RD on the six QC blinds of $+0.056 \%$, while a bias of only $+0.013 \%$ was observed in the last two days of the study by Analyst $A$. This does not affect the ceric data.

Using only days 3 and 4 provides an opportunity to compare the ceric titration to what may be considered normal potassium dichromate titration data. These data, though limited, may provide a better comparison of the potassium dichromate and ceric titration results. Table 5, which shows the combined results from both analysts for days 3 and 4 only, indicates that the potassium dichromate titrations are unbiased while the ceric titrations have a significant positive bias. The standard deviation is similar for both titrants and thus indicates similar levels of precision. This is reinforced by the similarity in the $95 \%$ confidence intervals of the mean, which includes an adjustment for the size of the sample (n). Table 6 shows the same statistics for each analyst-titrant combination for days 3 and 4 only. It should be emphasized that the data for days 3 and 4 parallels the combined data sets seen in Table 4, with the exception of the dichromate titration data from Analyst A.

\begin{tabular}{|c|c|c|c|c|}
\hline \multicolumn{4}{|c|}{$\begin{array}{c}\text { Table 5 } \\
\text { Comparison of Results of Samples Titrated with Cerium and } \\
\text { Potassium Dichromate Solutions for Days 3 and 4 }\end{array}$} \\
\hline \hline Titrant & $n$ & Mean \%RD & Std. Dev. & $95 \%$ C. I. \\
\hline Cerium & 24 & 0.038 & 0.024 & 0.010 \\
\hline$K_{2} \mathrm{Cr}_{2} \mathrm{O}_{7}$ & 16 & 0.008 & 0.021 & 0.011 \\
\hline
\end{tabular}




\begin{tabular}{|c|c|c|c|c|c|}
\hline & $\begin{array}{c}\text { Somparis } \\
\text { otassium }\end{array}$ & mate & $\begin{array}{l}\text { le } 6 \\
\text { amples Tutrat } \\
\text { ions by Anal }\end{array}$ & $\begin{array}{l}\text { Cerium } \\
\text { Days } 3 \text { an }\end{array}$ & \\
\hline Titrant & Analyst: & $\mathrm{n}$ & Mean \%RD & Std. Dev. & $95 \%$ C.I. \\
\hline \multirow{2}{*}{ Cerium } & A & 12 & 0.052 & 0.018 & 0.011 \\
\hline & C & 12 & 0.024 & 0.021 & 0.013 \\
\hline \multirow{2}{*}{$\mathrm{K}_{2} \mathrm{Cr}_{2} \mathrm{O}_{7}$} & A & 8 & 0.019 & 0.017 & 0.014 \\
\hline & C & 8 & -0.003 & 0.019 & 0.016 \\
\hline
\end{tabular}

While the precisions of the two methods were shown to be statistically equivalent, the statistically high bias $(0.035 \%)$ exhibited in the ceric titrations, coupled with the analyst-to-analyst variation observed, indicated that the ceric titration method warranted further study before the method could be put into general use.

The cause of the positive bias in the ceric titrations was investigated. A number of probable explanations for the bias were identified by these investigations. First, the endpoint determinations for the titrations were determined potentiometrically. One analyst during the study (Analyst A) detected a slow upward drift in the potential reading near the titration endpoint when the ceric titrant was used (as compared to a fairly rapid stabilization of the potential normally seen during addition of the last portion of dichromate titrant). This drift was not seen in the initial method development, nor was it observed by Analyst $C$ during the method testing. Investigations revealed that this drift faded with successive titrations. The sluggish electrode response may have contributed to the bias by causing undetected overtitrations. Apparently, there is a longer conditioning period for the platinum electrode when used for the ceric titrations, and care must be taken to assure the electrode behavior has stabilized to ensure consistent results.

The second probable cause for the bias concerned the vanadyl sulfate, which is added as a $0.075 \%$ solution just prior to titration so as to increase the kinetics of the titration reactions. Different production lots of vanadyl sulfate from the same company were used by Analysts $A$ and $C$ in the first study. The analytical procedure followed at NBL requires the titration of an analytical blank (which consists of all the reagents, but with no uranium present) which is used as a correction factor. A comparison of the two lots of vanadyl sulfate revealed that one lot caused noticeably higher values, and larger variability, for the ceric blank titrations. While a high blank does not necessarily contribute to a bias, a high value coupled with a larger variability can. The dichromate titrated blanks using one of the production lots varied from $0.0022 \mathrm{~g}$ titrant to $0.0008 \mathrm{~g}$ titrant over all the days of titrations in the two studies. With a typical titration requiring 8.0000 $\mathrm{g}$, the blank value represents a small and fairly consistent correction factor. In general, however, the ceric titration blank values were consistently higher. Blank values as high as $0.0082 \mathrm{~g}$ were observed in the 
original study. An error of $25 \%$ in the blank in this case would translate into a $0.025 \%$ bias. Apparently the ceric titrant is more sensitive than the dichromate titrant to impurities in the vanadyl sulfate solution, and it, therefore, is important to assure that each lot of vanadyi sulfate be tested before use. Since the presence of apparent impurities in the vanadyl sulfate solution was a concern, the effects of lowering the concentration of the vanadyi sulfate solution was tested. It was found that reducing the concentration of the vanadyl sulfate solution to values below $0.05 \%$ caused detectable sluggishness in the electrode response.

Another possible cause of the statistical bias that was detected in the ceric titration procedure is instability of the titrant. An initial investigation into the titrant stability (based on the periodic restandardization of two separate batches of titrant) indicated that the titrant, as prepared, does not have long-term stability. The preliminary study indicated a daily decrease as high as $0.001 \%$ in the titrant calibration factor was possible. The typical procedure at NBL entails standardizing the titrant on one day, and using the calculated factor on subsequent days. Thus, a small, but detectable part of the bias indicated in the statistical study may be attributable to a changing titrant factor. The evidence of ceric titrant instability prompted a more thorough statistical evaluation of the stability of the titrant. This is described later in this report.

The titration procedure was altered to minimize bias in the method, and an auxiliary statistical plan of analysis was developed. Care was taken to ensure that the electrodes were properly conditioned prior to starting analyses, and the unacceptable vanadyl sulfate was not used. The blanks were used as an indication of the conditioning of the electrodes; two blank titrations had to produce similar values, with no indication of sluggish electrode response, before the analysts were allowed to continue. This gave reassurance that the blank value used in the calculations was representative of a stable titration system. Additionally, any blank requiring more than $0.0060 \mathrm{~g}$ of titrant required the analyst to investigate the measurement system, since this amounted to an unacceptably high correction factor. As a result of the changes described above, no ceric titration blanks performed during the auxiliary study exceeded this preset limit. Finally, in order to minimize any potential bias caused by any titrant instability, the auxiliary plan required the analysts to complete their titrations within ten days of the titrant standardization.

One additional change was made to the protocol. The typical NBL procedure calls for titrant standardization using two sets of five samples each from previously prepared and verified standard uranium solutions. This procedure was followed in the initial study, using different: samples for the standardization of the ceric and dichromate titrant solutions from those used in the study. For the auxiliary study it was decided to use samples from the same uranium solution used in the study itself to determine the factor for the ceric titrant. This should eliminate any inherent bias caused by standardizing with samples from different uranium solutions, which could not be corrected for in the statistical plan design.

The auxiliary plan was not designed to directly compare the ceric titration procedure with the dichromate titration procedure, since the first plan gave us an indication of the relative precisions of the two methods. 
The auxiliary plan's main intent was to discern if the changes made to the ceric titration procedure resulted in a method that was unbiased and which contained no analyst-to-analyst-variation. For each data point a \%RD was calculated. Figure 2 shows the \%RD data (excluding outliers) by analyst and by day. The results from Day 0 , while presented in Figure 2, were not used directly in the statistical analysis since these results were used to determine the titrant standardization factor. The mean \%RD for both analysts for Day 0 is $0.000 \%$. The results of the statistical analysis of the \%RD data of the two analysts, consisting of a total of 31 titrations each (results from two titrations were outliers), are presented in Table 7.

\begin{tabular}{|c|c|c|c|c|c|}
\hline & \multicolumn{5}{|c|}{ Descriptive Statistics for cerium Ttrations } \\
\hline Analyst & $n$ & Mean $\% R D$ & Std. Dev. & $95 \% \mathrm{Cl}$ & $95 \%$ C.I.** \\
\hline 1 & 31 & 0.0048 & 0.0197 & 0.0072 & \\
\hline 2 & 31 & 0.0100 & 0.0270 & 0.0099 & \\
\hline COMBINED & 62 & 0.0074 & 0.0236 & & 0.0138 \\
\hline
\end{tabular}

Evaluation of the \%RD data revealed no statistically significant bias, nor any analyst-to-analyst variation in the procedure. However, the \%RD data did show a highly significant (> 99\% significance) analyst-day-toanalyst-day variation. Standard statistical techniques of analysis of variance (ANOVA) were applied to the data to estimate all uncertainty components, including the within-day standard deviation, the standard deviation due to analysis day, and the total standard deviation of an observation and of the mean \%RD. These results are presented in Table 8 . While statistically significant, this day-to-day variation is small $(0.015 \%)$ and is only detectable because of the high precision of the analysts' results within each day. Statistically combining the mean \%RD and the standard deviation of the \%RD for a single measurement gives a value of $0.031 \%$.

Although no direct statistical comparison of the ceric titrant with the potassium dichromate titrant was done in this auxiliary study, an indirect comparison can be made. The results obtained during the same period by the two analysts on the NBL Titrimetric Method using potassium dichromate titrant (titrating QC blinds) are compared in Table 9 with the results they obtained using the cerium titrant. Both titrants appear to produce similar results; overall the spread of the data (as evidenced by the standard deviations of the \%RDs) are quite narrow for both analysts, and no significant biases can be seen. 


\begin{tabular}{|c|c|c|c|c|c|}
\hline \multicolumn{6}{|c|}{$\begin{array}{c}\text { Table } 8 \\
\text { Arnalysis of Relattue Difference Data }\end{array}$} \\
\hline Mean \%RD & $\begin{array}{l}\text { Error STD } \\
\ldots\end{array}$ & Day STD & Std Dev & Std. Mean & $\begin{array}{l}95 \% \text { C.I. } \\
\text { Mean }\end{array}$ \\
\hline 0.0074 & 0.0189 & 0.0151 & 0.0241 & 0.00583 & \pm 0.01378 \\
\hline d.f. & 54 & 5 & 28 & 7 & 7 \\
\hline $\begin{array}{l}\text { Mean \%RD } \\
\text { Error STD } \\
\text { Day STD } \\
\text { Std. Dev. } \\
\text { Std. Mean } \\
95 \% \text { C.I. } \\
\text { d.f. } \\
\text { All quantities }\end{array}$ & \multicolumn{5}{|c|}{ 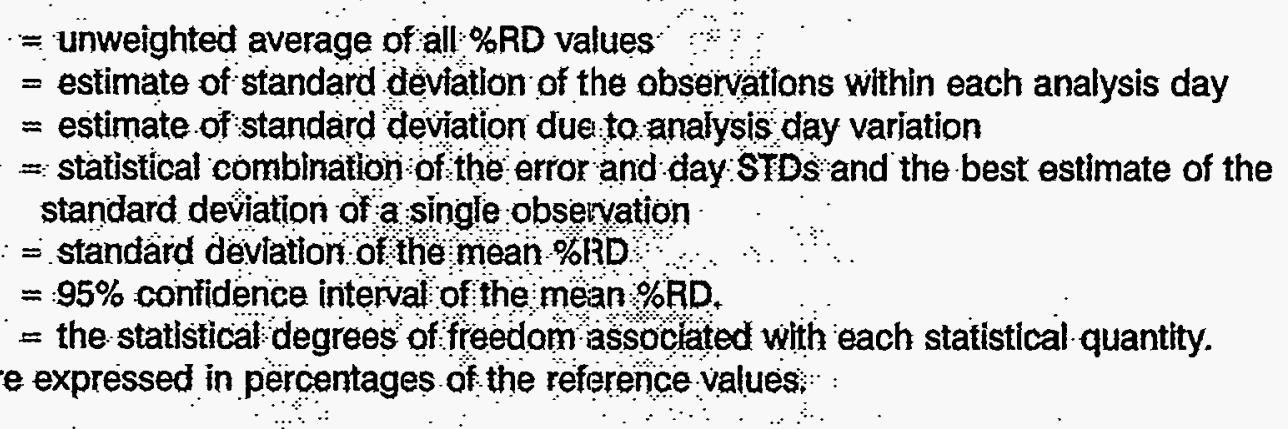 } \\
\hline
\end{tabular}

\begin{tabular}{|c|c|c|c|c|c|c|}
\hline \multicolumn{7}{|c|}{ Comparison of Potassium Dichromate and Cerium Titrant Precisions } \\
\hline & \multicolumn{3}{|c|}{ Cerium Titrant } & \multicolumn{3}{|c|}{ Potassium Dichromate Titrant * } \\
\hline Analyst & $\mathbf{n}$ & Mean \%RD & Std. Dev. & $n$ & Mean \%RD & Std. Dev. \\
\hline 1 & 31 & 0.005 & 0.020 & 40 & 0.007 & 0.037 \\
\hline 2 & 31 & 0.010 & 0.027 & 40 & 0.020 & 0.027 \\
\hline
\end{tabular}

The changes in the procedure had the desired effect of eliminating bias and analyst-to-analyst variation. A complete description of the procedure used can be found in the appendix. 


\section{Cerium Titration Results \%RDs by Day}

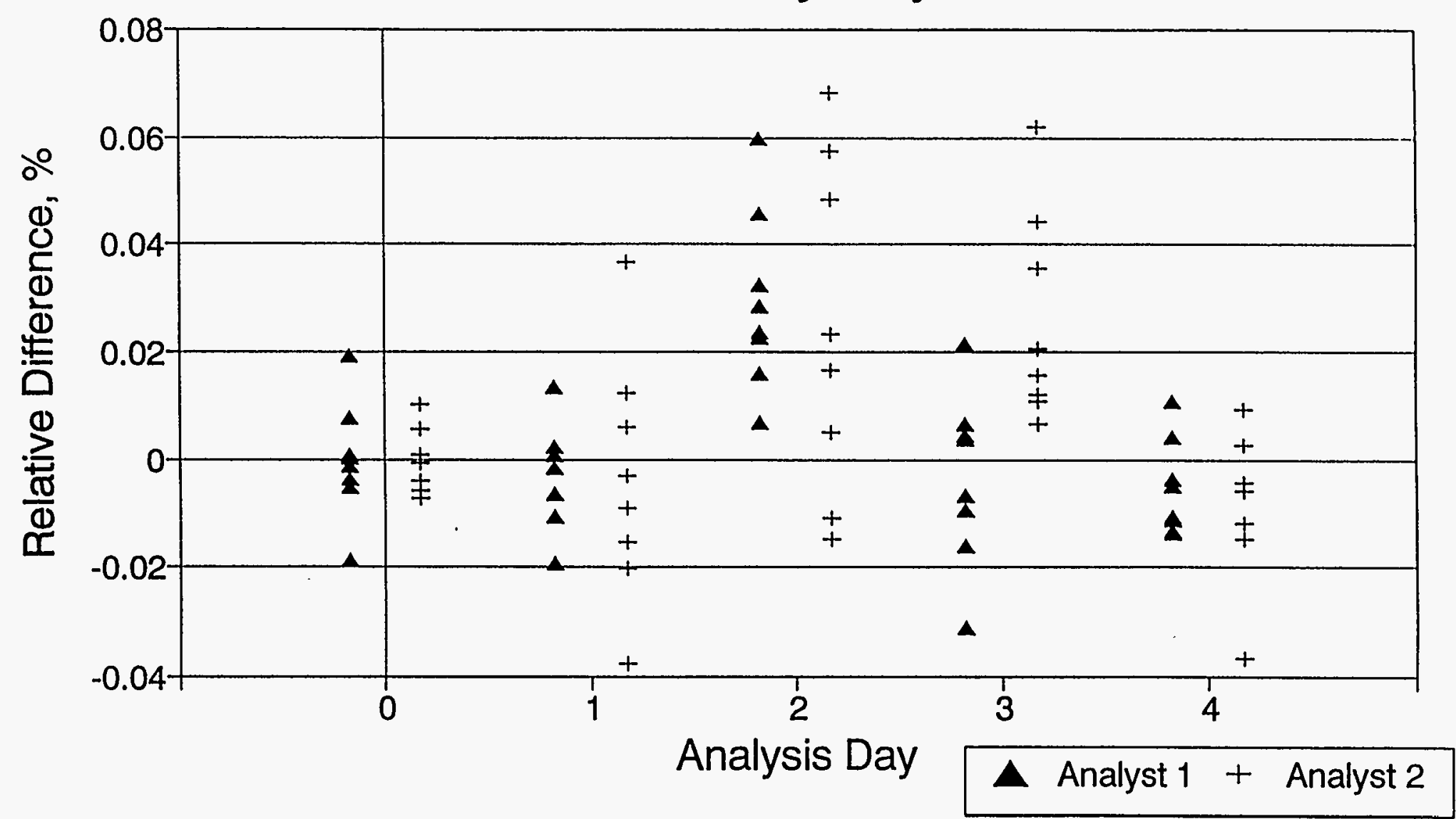

Figure 2. Auxiliary Statistical Plan Results Excluding Outliers 


\section{EFFECTS OF IMPURITIES ON THE CERIC TITRATION METHOD}

\section{Statistical Plan}

A Plan of Analysis was prepared for the testing of the effects of impurities on the ceric titration procedure. All uranium samples were prepared from the same master solution used for the auxiliary plan of analysis for the testing of pure uranium. No dichromate titrations were performed. All QC samples were titrated with the ceric titrant. The ceric titrant was standardized using eight uranium samples from this master solution. Ten metal impurities were chosen for testing, and the titration of samples containing these ten impurities were completed over four titration days. Three impurities, were tested on each of the first three days, and on the fourth day the last impurity was tested.

The schedule of titrations is presented in Table 10. The ten impurities are designated impurities A, B, C, D, $E, F, G, H, J$, and $K$ (the letter I was not used). Three samples of an impurity were titrated on a single day; samples, overtitrated or otherwise determined to be questionable, were replaced with a prepared spare of the same impurity. The statistical plan allowed for repeating any of the impurities in which one or more of the titrations were determined to be outliers, or where the standard deviation of the triplicate \%RDs is greater than $\mathbf{0 . 0 2 5 \%}$ or greater than the standard deviation of the pure samples titrated that day. These additional titration samples are referred to as impurities R1, R2, and R3 in Table 10.

\section{Results and Discussion}

In the experiments described in the previous section, the substitution of the potassium dichromate titrant with a cerium(IV)-based titrant was found to cause no deleterious effects on the NBL Titrimetric Method's performance on pure uranium samples, so long as care is taken in the conditioning of the electrodes. These findings, based on the titration of pure uranium samples, cannot be assumed to apply to samples with impurities. The NBL Titrimetric Method, with potassium dichromate as the titrant, has been widely tested for the effects of impurities. The greater oxidizing strength of the ceric ion has the potential to cause problems not observed in dichromate titrations.

The effects of the presence of ten metal impurities (Cu, Ti, Co, Ni, Na, Mg, Gd, $\mathrm{Zn}, \mathrm{Cd}$, and $\mathrm{Cr}$ ) were tested. These ten impurities are commonly found in uranium samples received at NBL and were chosen as representatives of the different metal groups, i.e., alkali, alkaline earth, transition, and rare earth metals. It was not practical to test all common impurities, nor was it considered necessary. In the planning of this phase of the project, it was assumed that if an impurity causes a bias because that species is titratable by dichromate, it will be titratable with $\mathrm{Ce}$ (IV) also. Likewise, if an impurity is known to precipitate and occlude uranium, or if it is known to interfere with the electrode response, it will do this regardless of the titrant and therefore would not be tested. In effect, only those impurities which were previously shown to cause no bias 
in the NBL Titrimetric Method using potassium dichromate as the titrant were tested with the ceric titrant. Each impurity was tested at $10 \mathrm{mg}$ per $20-40 \mathrm{mg}$ uranium. This level was considered large enough to encompass the amount of impurities found in a majority of samples analyzed at NBL.

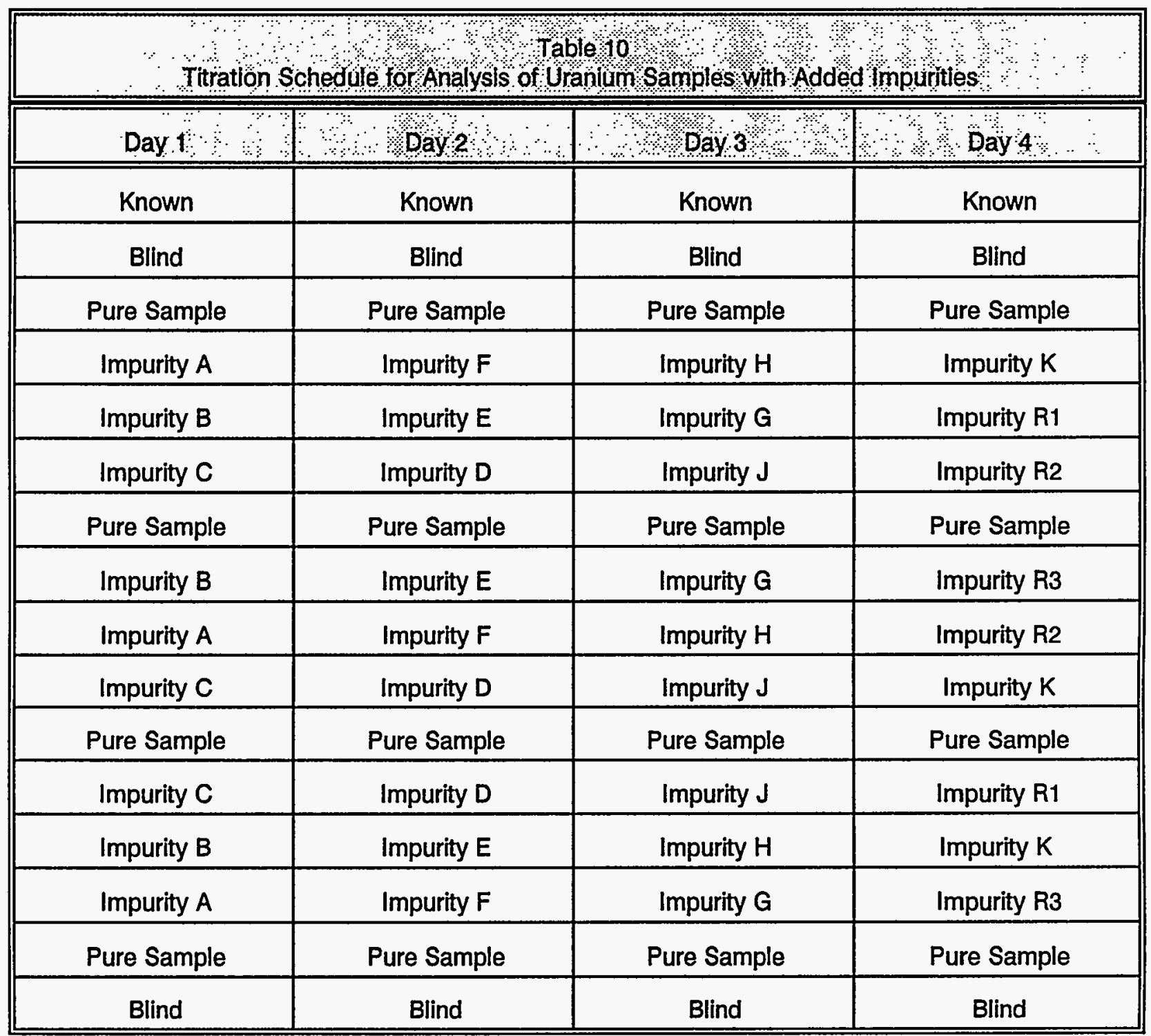

The statistical plan tested the effect of only one impurity at a time. No combination of impurities was tested.

The statistical plan sought only to determine if the impurity, at the given mass level $(10 \mathrm{mg})$, had any significant effect on the measurement. Because the ceric titration method was found to have no significant analyst-to-analyst variation, the effect of each impurity was tested by one analyst experienced with the procedure (a total of two analysts performed the tests on the ten impurities). Day-to-day differences in the analysis of pure uranium were observable primarily due to the good within-day precisions of the titrating 
analysts. To account for the effects of day-to-day variations, titrations of uranium samples from the same uranium solution, without added impurities, were titrated.

The results of the statistical analysis are presented in Table 11. $\mathrm{Cu}, \mathrm{Ti}, \mathrm{Co}$, and $\mathrm{Ni}$ were all added as +2 ions, while $\mathrm{Cr}$ was added as $\mathrm{Cr}$ (III). All other metals added were in their common stable oxidation states. All the elements (excluding $\mathrm{Ti}$ and $\mathrm{Cr}$ ), caused no statistically significant bias in uranium measurements at the level used. The presence of $\mathrm{Ti}^{2+}$ was found to cause a bias of $-0.05 \%$. This has been attributed to the presence of sulfate ions (present from the original dissolution of the uranium metal), resulting precipitation of titanium sulfate and the occlusion of uranium. A similar effect has been observed with uranium in the presence of barium. ${ }^{5}$ The appearance of a precipitate was clearly seen in the titration with titanium present. Attempts to fume to the samples with fuming acid (a combination of perchloric, nitric and sulfuric acids) prior to analysis did not eliminate the bias. Additional fumings may have been required to decreased or eliminate the bias, but were not attempted in this study.

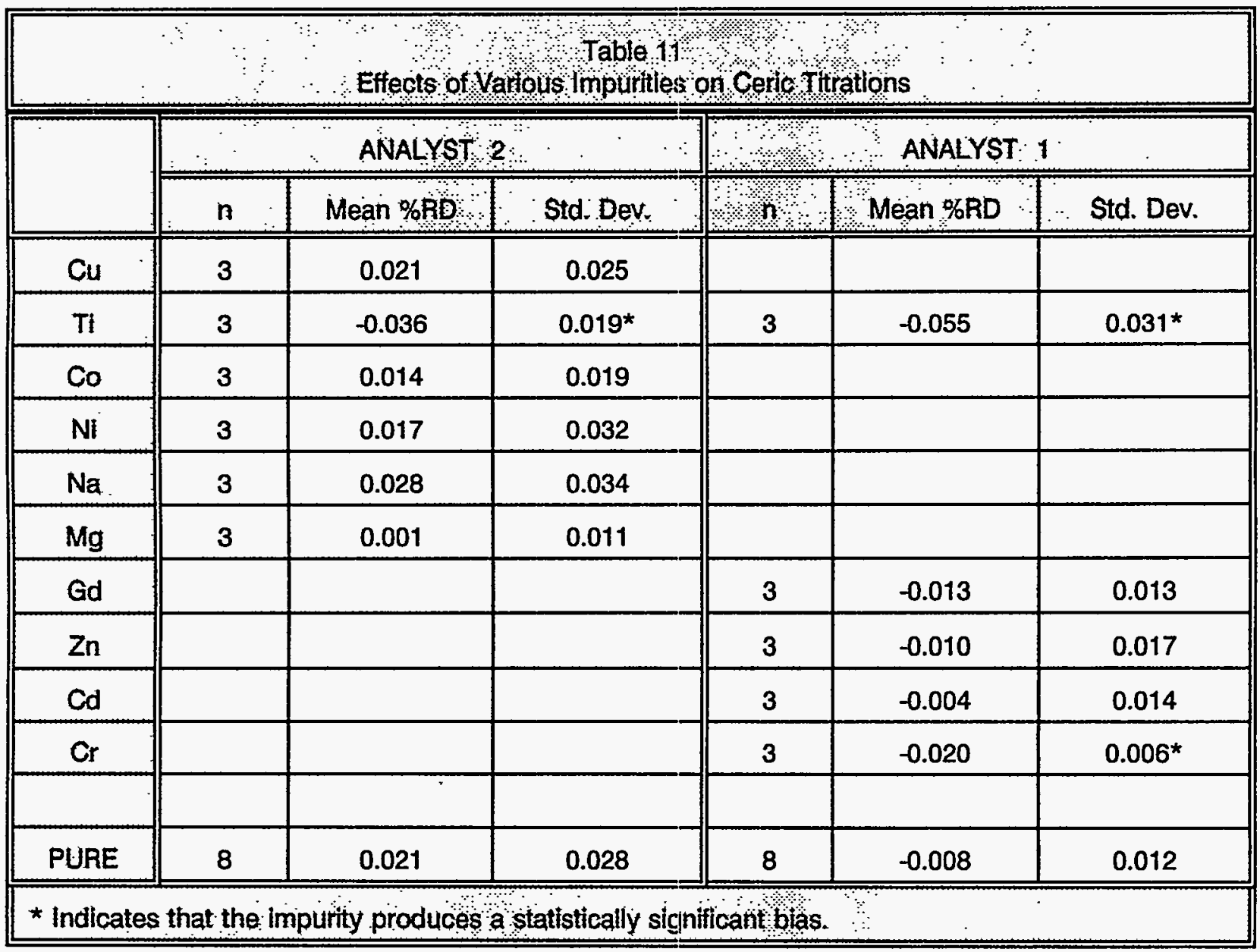


A slight negative bias was observed results from titrations of aliquants containing $\mathrm{Cr}$. However, these titrations exhibited tight precision, showing only half the variation seen in the sets of aliquants with the other impurities. While statistically significant, the observed bias relative to the pure samples was physically small $(-0.012 \%)$.

While not conclusive (in that all impurities were not tested), these results give a good indication that the presence of impurities will have similar effects in both the ceric and dichromate titration methods.

\section{STABILITY OF $0.027 M$ CERIC AMMONIUM NITRATE IN $1 M \mathrm{H}_{2} \mathrm{SO}_{4}$.}

\section{Statistical Plan of Analysis}

A plan of analysis was created to quantify the rate of instability in the ceric titrant. This study was conceived as a follow-up study to the cerium titration auxiliary study previously discussed. In that study, aliquants of a standard uranium solution were titrated by two NBL analysts for five days (eight samples per day) within a two week period. The five days of titration are referred to as Days 0 through 4 (Day 0 referring to the titrant standardization day). Additional aliquants of the same uranium standard solution were titrated with the same ceric titrant during a several month period by the same two analysts (Analyst 1 and 2). Both analysts titrated aliquants of uranium standard solution on two intermediate days (Days 5 and 6), and finally used the same titrant solution for three additional days of titration (Days 7, 8 and 9) approximately five months after the initial titration days. The daily schedule of titration is the same as the one outlined in Table 2 , with the exception of Days 8 and 9 in which each analyst titrated four samples of pure uranium along with quality control samples (see discussion for more details). The data were evaluated using the original titrant standardization factors (based on the first titration day) and on composite factors based on a factor determined from the first three days of titration and on the first five days of titration.

Three outllers were removed from the first five days of data during the original study. One outlier was detected in the additional titration days. The last two titration days had only four aliquants of pure uranium each day. The other aliquants titrated those days were spiked with various impurities and were used for the impurities study discussed in the previous section.

Results and Discussions

The procedure at NBL for the potassium dichromate titrant preparation requires an initial standardization of a batch of titrant, with no need to restandardize unless there is some indication that the titrant factor has changed, e.g., if quality control samples are demonstrating a bias over a period of time. Preliminary results 
suggested that the ceric titrant used in this study lacks the long-term stability that the potassium dichromate titrant is known to possess. A statistical plan was designed to give a quantitative measure of how stable the titrant was over time and how long the titrant, as prepared and stored, could be used without having to be restandardized.

Using each analyst's Day 0 titration data to determine the ceric standardization factor, the relative difference from the prepared value (in percent) was determined for each aliquant of standard uranium solution. These data are illustrated on Figures 3 and 4 for Analyst's 1 and 2, respectively (excluding outliers). A decrease in the ceric titrant's oxidizing strength, resulting in an increasingly positive bias over time for both analysts, is evident from these plots. The degree of change appears to be consistent for both analysts.

The original design of the statistical plan had the two analysts involved in the testing of pure uranium samples continue with three additional titration days (using the same daily titration scheme) spread out over a five month period. Whereas for both analysts Days 0 through 4 were all titrated within a 10 day period, samples for Days 5, 6 and 7 were titrated at a minimurn of 1 month intervals. For each analyst it was anticipated that a simple linear regression analysis of the \%RD results generated from the two analysts' data would result in a statistically based stability factor (in terms of \% decrease in standardization factor per unit time). However, it became obvious that the data obtained would not support this type of analysis. This is largely because of the significant day-to-day variation observed in these ceric studies (which, in part, is observable because of the precision in the measurements of the titrating analysts). The superimposition of the day-to-day variation on any titrant instability effect made it impossible to quantify any trend in the manner that had been originally planned.

The data analysis that was subsequently performed was aided by the availability of additional measurement values. The last two days of data for each analyst (Days 8 and 9) are taken from the unspiked uranium samples titrated with the same ceric titrant during the impurities study. Since the standard uranium solution used in the impurities study was from the same stock solution used in Days 0 through 7 , and since all samples were titrated under the same conditions, it was cletermined that the use of these values was valid.

Days 8 and 9 were completed by both analysts within three days of the Day 7 titration. Since Days 7,8 , and 9 were titrated within a narrow time-frame, any variation in the between-day results should be mainly due to day-to-day variation of the method with only an undetectable instability component. The same holds true for titration Days 0 through 4. By basing the analysis on these two groupings of data, the effects of day-today variations can be mitigated (i.e. "canceled out") and a trend representing the effects of the titrant factor change can be detected. The intermediate results from Days 5 and 6 were not used in the analyses. 


\section{Cerium Titration Results}

\section{Analyst 1}

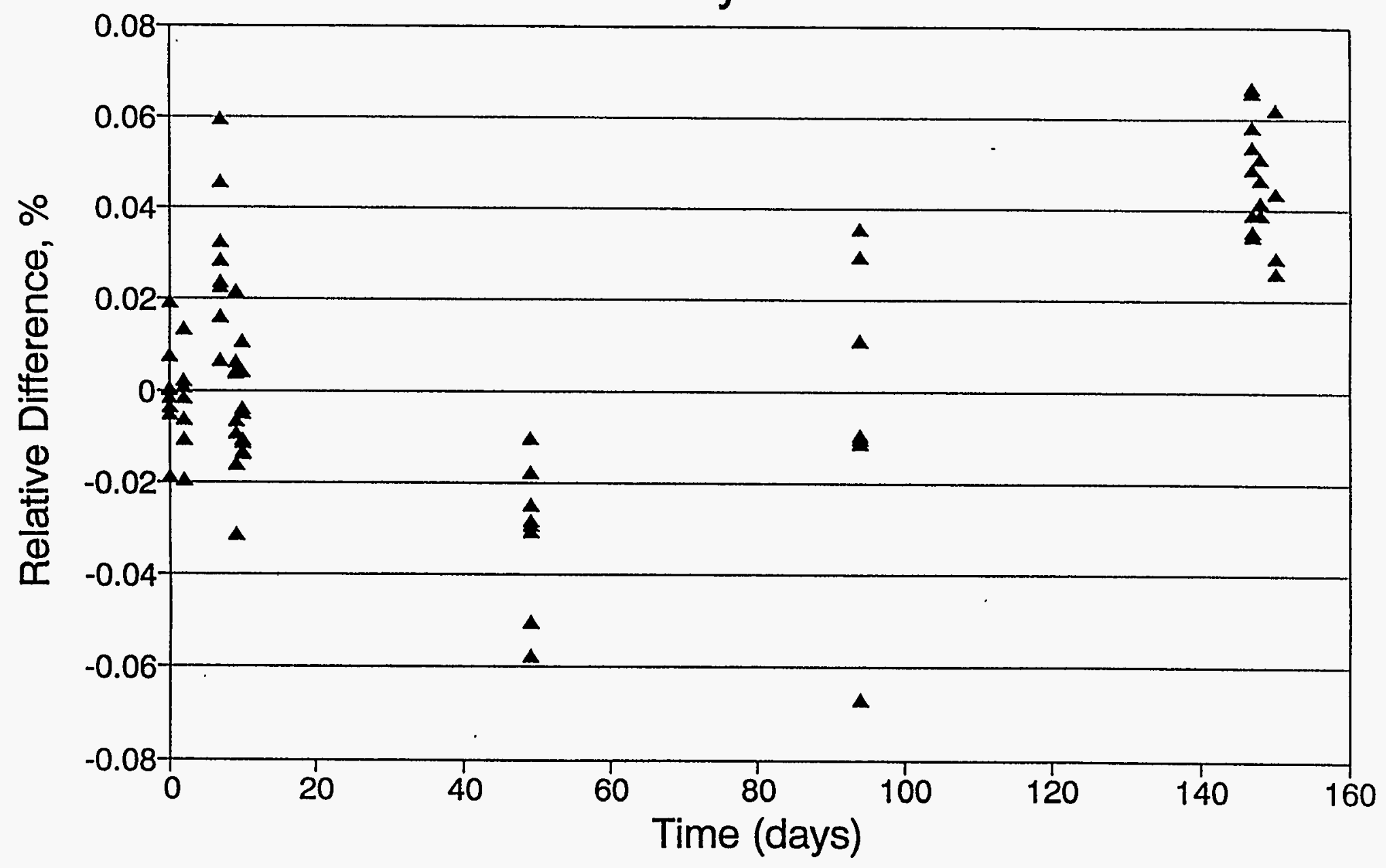

Figure 3. Ceric Titration Results as a Function of Time 


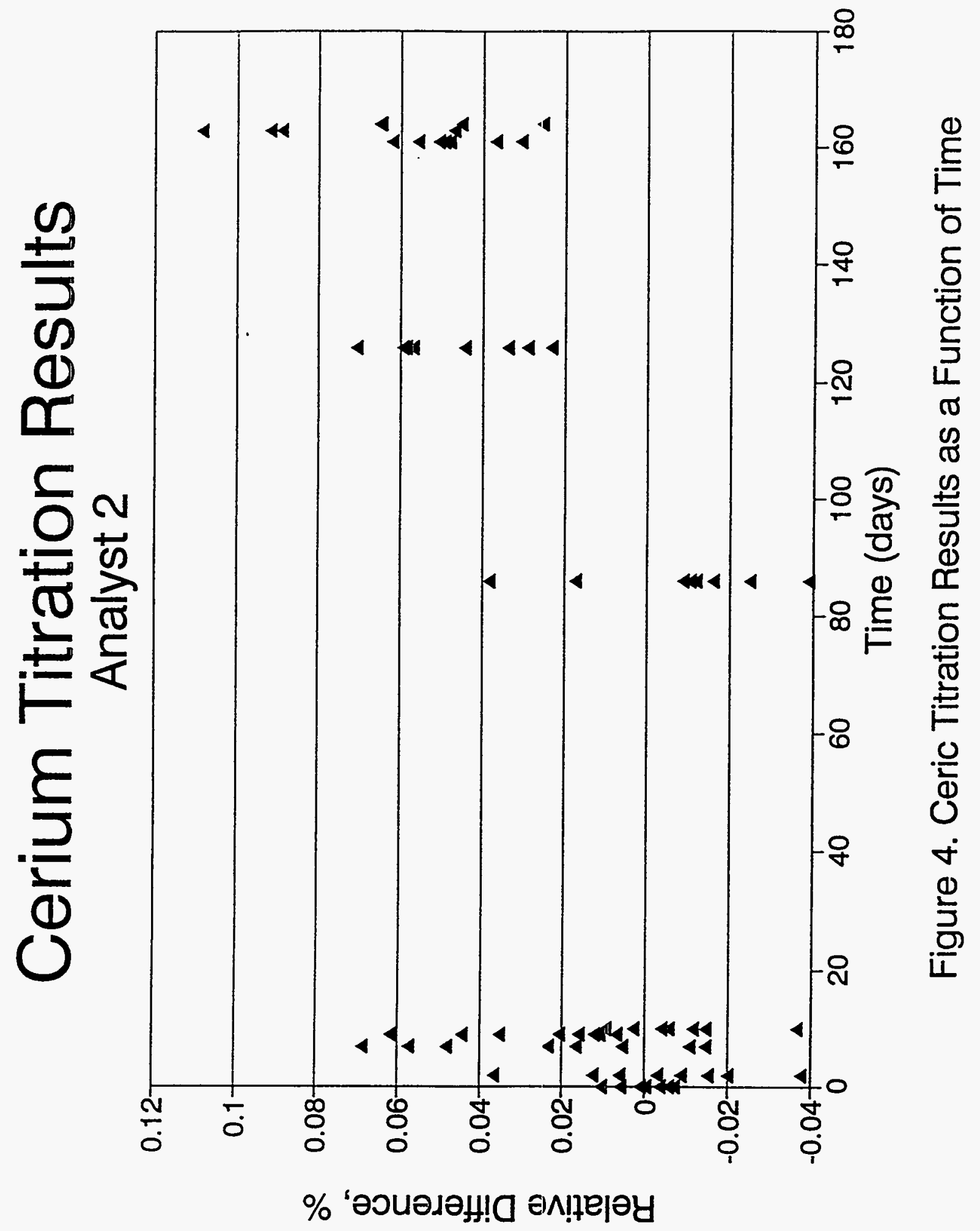


The uranium titration results were first analyzed using only the first three days' (Day 0 through Day 2) titration data and the last three days' results. A titrant standardization factor was calculated based on the first three days of titration, and \%RDs were calculated for all samples based on this titrant factor. The mean \%RD and the standard deviations of the \%RD values for the first three days combined, and the last three days combined, is presented in Table 12 for both Analysts 1 and 2. The results were also analyzed using the first five days of titration data (Day 0 through Day 4) to calculate the titrant factor. The mean \%RD and the standard deviations of the \%RD values for the first five days combined, and the last three days combined, are presented in Table 13. A statistically significant and consistent bias in clearly indicated by these calculations.

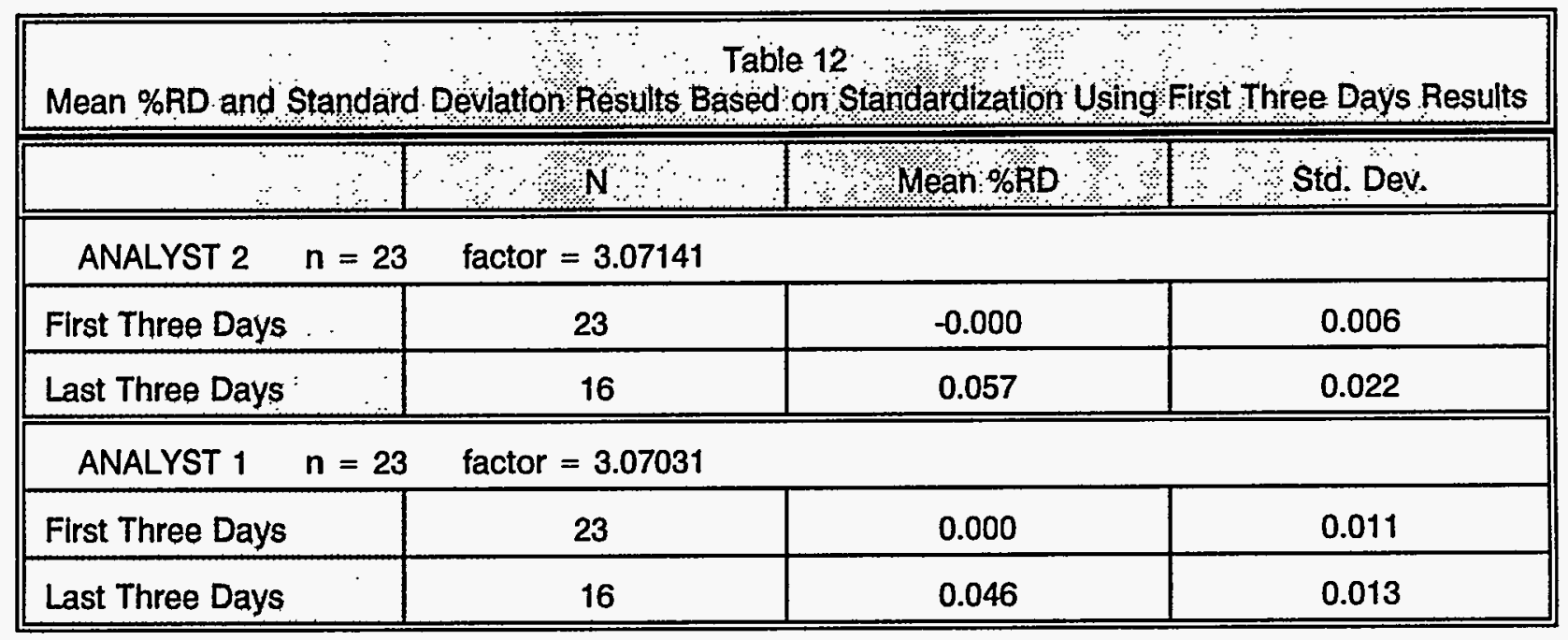

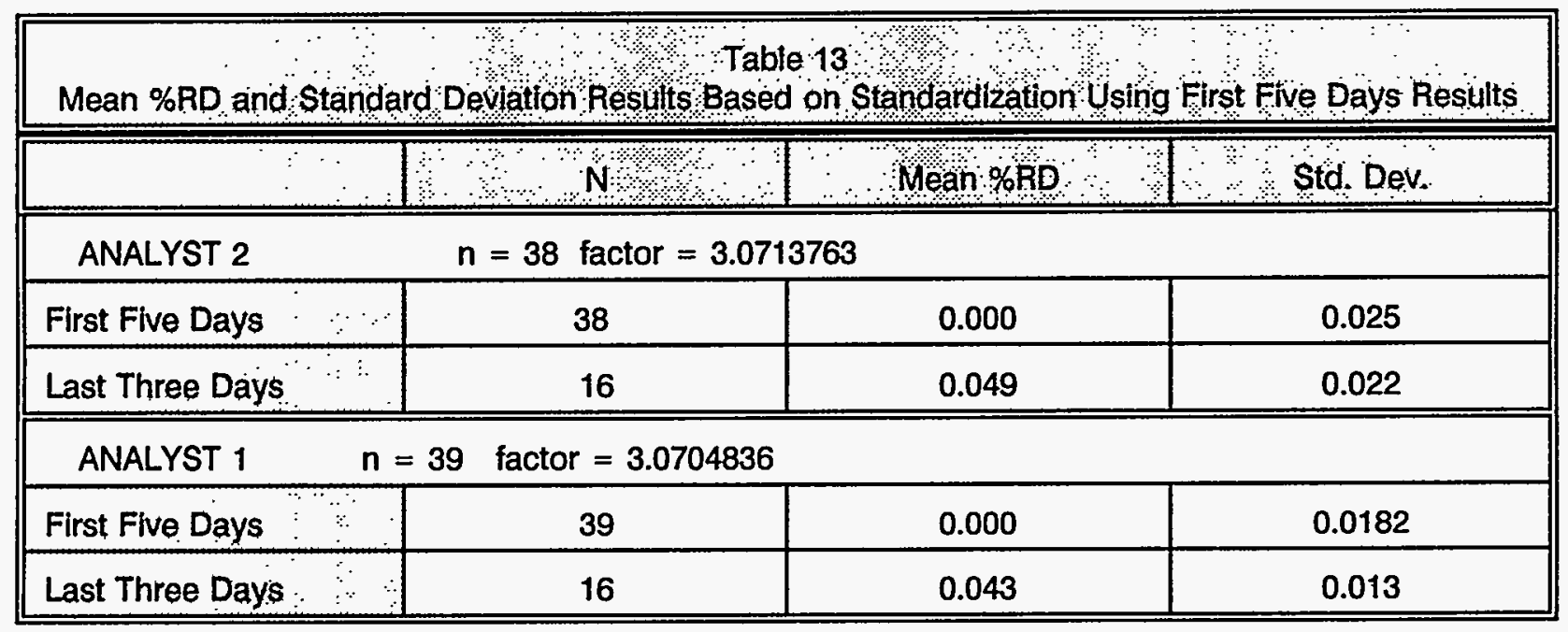

In order to quantify the trend, the \%RD data was subjected to a regression analysis. The data was analyzed using a data set combining the first three days and last three days of titration results for each analyst, and 
also using a data set combining the first five days and last three days. Results of the regression analyses of both data sets is presented in Table 14. The $R^{2}$ statistic indicates the amount of variation in the data set that is explained by the variation in time, expressed as a percentage. The slope of the regression analysis essentially gives the daily change in the titrant factor. The analyses gave consistent results between analysts, while the difference between the three day and five day factoring is negligible. Thus the data indicates an expected decrease in the titrant's standardized factor of approximately $0.01 \%$ per month.

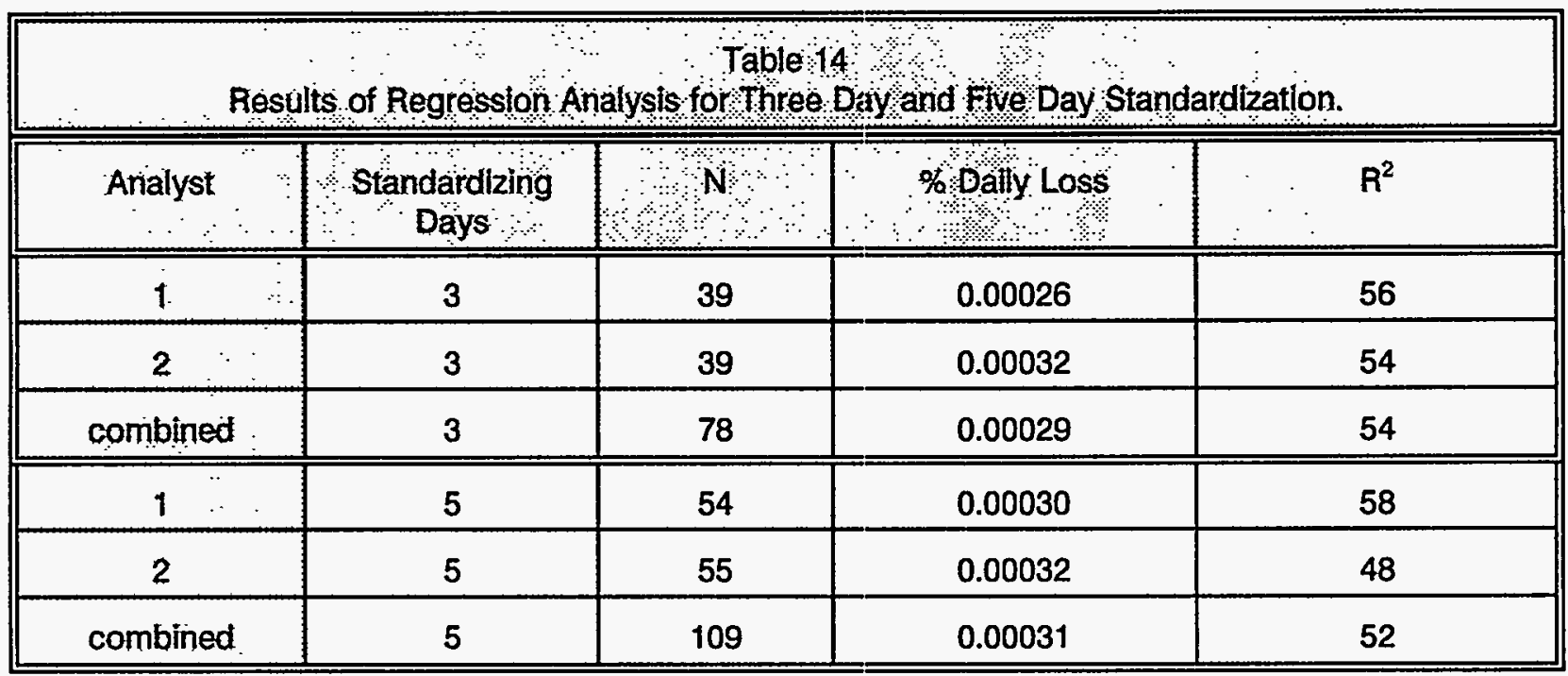

The ceric titrant was stored in the same manner as the dichromate titrant, in tightly-capped glass bottles. The bottles are commonly weighed to detect loss of water by evaporation. No other special precautions were made to protect the ceric titrant. The cause of the instability has not yet been determined. It could be that there is a "curing" process involved in the storage of the titrant. It is also possible that the instability is caused by the presence of the nitrate ion from the ceric ammonium nitrate salt. Future plans include testing of a different ceric titrant, derived from ceric sulfate, for long-term stability.

It should be noted that many facilities that use the NBL Titrimetric Method standardize their titrant daily. Therefore, the stability of the ceric titrant for these facilities is not a concern, since the effects of any instability could only be detected over numerous days using the same factor, and the very slow degradation of the titrant does not appear to interfere with the method's precision. In fact, calculating a titrant factor daily would eliminate the statistically observed day-to-day variation of the method, thus increasing the overall precision. 


\section{CONCLUSION}

Substitution of the potassium dichromate in the NBL. Titrimetric Method with a ceric titrant can be effected without any loss of precision or accuracy in the determination of uranium in pure uranium samples. The ceric titration procedure, however, is much more sensitive to the condition of the electrode, as well as the quality of the reagents. Unbiased results can be readily obtained, however, with proper attention to the responsiveness of the system. The tests on the effects of impurities on the method performance, while clearly not comprehensive, gave clear indications that there should be no significant difference between the dichromate and ceric titration methods.

The ceric titrant used in this study, as prepared, showed slow degradation of its oxidizing ability. The titrant degradation, while significant, is sufficiently slow to allow for analysis of samples over an extended period of time without the need to recalculate a titrant factor.

\section{REFERENCES}

1. L. Z. Bodnar and M. W. Lerner, "Ruggedness Testing of the New Brunswick Laboratory Titrimetric Method of Determining Uranium," NBL-272 (1974), pp. 13-25.

2. A. R. Eberle, M. W. Lerner, C. G. Goldbeck, and C. J. Rodden, "Titrimetric Determination of Uranium in Product, Fuel, and Scrap Materials After Ferrous Ion Reduction in Phosphoric Acid. Part I. Manual Titration," NBL-252 (1970), pp. 1-25.

3. D. G. Peters, J. M. Hayes, G. H. Hieftje, "Chemical Separations and Measurements," p. 319, Saunders Publishing Company.

4. W. Davies and W. Gray, "A Rapid and Specific Titrimetric Method for Precise Determination of Uranium Using Iron(II) Sulfate as Reductant," Talanta 11, 1203 (1964).

5. A. R. Eberle and M. W. Lerner, "Titrimetric Determination of Uranium in Solutions Containing Mercury," NBL-258 (1971), pp. 26-32.

J. M. Scarborough, "The Effects of Impurities on the Determination of Uranium by the New Brunswick Laboratory Titrimetric Method," NBL-265 (1972), pp. 26-27.

J. M. Scarborough and L. Z. Bodnar, "The Effect of Impurities on the New Brunswick Laboratory Titrimetric Method of Determining Uranium. II. Platinum Metals, Chloride and Bromide," NBL-267 (1973), pp. 6-12.

L. Z. Bodnar and J. M. Scarborough, "The Effect of Impurities on the New Brunswick Laboratory Titrimetric Method of Determining Uranium. III. Fluoride," NBL-267 (1973), pp. 13-16.

L. Z. Bodnar, M. W. Lerner, and J. M. Scarborough, "The Effect of Impurities on the New Brunswick 
Laboratory Titrimetric Method of Determining Uranium. V. Silver, Gold, Lead, lodine, Arsenic, Antimony, and Bismuth," NBL-272 (1974), pp. 5-8.

L. Z. Bodnar, "The Effects of Impurities on the NBL Titrimetric Method of Determining Uranium," NBL-277 (1976) pp. 4-6.

6. A. R. Eberle and M. W. Lerner, "Elimination of Manganese in the New Brunswick Laboratory Titrimetric Method of Determining Uranium," NBL-262 (1972), pp. 21-24.

L. Z. Bodnar, J. M. Scarborough, and M. W. Lerner, "A Study of the Elimination of the Manganese Interference in the New Brunswick Laboratory Titrimetric Method of Determining Uranium, " NBL-265 (1972), pp. 22-25.

L. Z. Bodnar, J. M. Scarborough, and M. W. Lerner, "Elimination of Some Interferences in the New Brunswick Laboratory Titrimetric Uranium Method by Means of a Copper Column," NBL-267 (1973), pp. 19-21.

7. B. W. Moran, "The Effects of Variation in Temperature and Procedure on the NBL Modified Davies and Gray Titration for Uranium," Draft Report. 
APPENDIX

PROCEDURE FOR URANIUM DETERMINATION BY CERIC TITRATION 
- 


\section{INTRODUCTION}

\section{A. Applicability}

This method may be used to determine uranium content of pure product material samples such as $\mathrm{U}$ metal, $\mathrm{UO}_{2}, \mathrm{UNH}$, and $\mathrm{U}_{3} \mathrm{O}_{8}$ from the nuclear fuel cycle. The use of the method to perform uranium measurements to better than a $0.1 \%$ precision and accuracy has an advantage over the NBL Titrimetric Method ${ }^{1}$ since it does not generate a RCRA mixed waste. The method may not be applied to scrap or waste samples until such time as it is qualified by obtaining results statistically equivalent to those obtained by the NBL Titrimetric Method on the same sample types.

\section{B. Summary of Method}

Uranium samples are dissolved and the solutions are aliquanted into samples containing 20 to $45 \mathrm{mg} \mathrm{U}$. Interferences are removed, and the aliquant is evaporated to dryness. The sample aliquant is redissolved and the uranium is reduced to $U(I V)$ with ferrous sulfate in a strong phosphoric acid solution. Excess $\mathrm{Fe}$ (II) is removed by molybdate-catalyzed oxidation with nitric acid. The aliquant is diluted with a vanadyl solution, which improves the rate of the titration reaction, and U(IV) is titrated with $\mathrm{Ce}(\mathrm{IV})$ to $U(\mathrm{MI})$.

Sulfamic acid is used to remove nitrites which can interfere with the ferrous reduction and with uranium titration. $\mathrm{Ce}$ (IV) is added to the phosphoric acid before use to oxidize the commonly-found impurity antimony to $\mathrm{Sb}(\mathrm{M})$, which does not interfere.

\section{Method Performance}

Assuming the absence of interfering impurities, most uranium solutions are assayed without statistically significant bias. Due to the statistical similarities between the ceric and dichromate titration procedures, the relative standard deviation for samples between 20 and $45 \mathrm{mg}$ uranium is expected to be less than $0.10 \%$. 
D. Interference/Limitations

Reagent temperatures must remain between $23^{\circ}$ and $31^{\circ} \mathrm{C}$ for all reactions to proceed properly. ${ }^{2}$ Normally, room temperature is maintained at $24 \pm 1^{\circ} \mathrm{C}$. If room temperature changes throughout the day, the balance used in weight titration must be periodically recalibrated.

Once phosphoric acid has been added, the titration must be completed; if the sample mixture cools it will not obtain a temperature great enough for complete oxidation of excess ferrous ion.

Aliquant volumes greater than $15 \mathrm{~mL}$ prevent pretitration reactions from going to completion. In volumes less than $12 \mathrm{~mL}$, sulfamic acid may precipitate upon addition of phosphoric acid, which can occlude uranium. ${ }^{3}$

Titration must be completed within 5 minutes of sample dilution with vanadyl solution, or air oxidation will cause negative assay errors.

Chemical interferences have not yet been fully determined. Preliminary results indicate that the chemical interferences using the ceric titrant should be similar to those for the dichromate procedure.

\section{E. Traceability to Primary Standards}

Uranium content is calculated by determining the amount of $\mathrm{Ce}(\mathrm{IV})$ used in titration. The titrant is standardized against CRM 112-A; with supervisory approval, other NBL-certified uranium reference materials may be used.

\section{F. Safety Procedures}

Material Safety Data Sheets (MSDS) should be reviewed prior to performing the procedure. Sulfuric, nitric, perchloric, hydrofluoric, and phosphoric acids are very corrosive and can cause painful burns. Wear gloves, safety glasses or goggles, and labcoats when handling. If acid contacts the skin, flush the affected area with water. If a burn results from acid contact, seek medical treatment. Hydrofluoric acid is difficult to remove completely and requires long flushing. Medical treatment is mandatory for all skin contact with hydrofluoric acid. Serious HF burns may not exhibit initial symptoms or pain. 
Perchloric acid may not be used on samples containing appreciable amounts of organics because of the danger of explosive reactions. Nitric acid should added to all perchloric acid fumings; at least twice as much nitric acid as perchloric acid should be used. Perchloric acid fumings should be performed only in a perchloric acid fume hood.

\section{INSTRUMENTS, APPARATUS, AND REAGENTS}
A. Instruments

1. Balance, readable to $0.0001 \mathrm{~g}$, preferably with push button tare capability.

2. $\mathrm{pH}$ meter, capable of reading absolute $\mathrm{mV}$.

B. Apparatus

1. Graduated cylinder, $100-\mathrm{mL}$.

2. Pipets, 5-mL and $10-\mathrm{mL}$.

3. Beakers, 400-mL.

4. Magnetic stirring bars, Teflon" coated

5. Magnetic stirrer.

6. Timer.

7. Indicating electrode. Pt wire (16-gauge, $99.99 \%$ pure) about 15 inches long, coiled at one end.

Clean platinum electrodes used for sample titrations daily by flaming to a white heat and quenching in concentrated nitric acid. Electrodes previously used for extremely "dirty" samples may be cleaned by dipping in molten sodium bisulfate or a saturated solution of sodium bisulfate, then flaming. 
8. Reference electrode. Commercially available saturated calomel. Cracked bead or asbestos junctions are preferred.

9. Polyethylene squeeze bottle, $125 \mathrm{~mL}$ capacity, fitted with a removable polyethylene tip drawn out to deliver drops weighing $\leq 5 \mathrm{mg}$.

10. Thermometer, calibrated.

\section{Reagents}

All reagents are ACS reagent grade. Solutions may be prepared in multiples or fractions as required to minimize wastes. NOTE: Reagents must be at room temperature before use in the assay procedures (Sections III.B and III.C).

1. Nitric acid, $70.4 \%$.

2. Perchloric acid, $70.5 \%$.

3. Hydrofluoric acid, $49.0 \%$.

4. Sulfuric Acid, $9 \mathrm{M}$. Add $1 \mathrm{~L}$ concentrated $\mathrm{H}_{2} \mathrm{SO}_{4}$ to about $800 \mathrm{~mL}$ distilled water, cool and dilute to $2 \mathrm{~L}$

5. Ceric sulfate, $0.4 \mathrm{~N}$. Dissolve $13.5 \mathrm{~g}$ anhydrous $\mathrm{Ce}\left(\mathrm{SO}_{4}\right)_{2}$ or $16.5 \mathrm{~g} \mathrm{Ce}\left(\mathrm{SO}_{4}\right) .4 \mathrm{H}_{2} \mathrm{O}$ or $21.9 \mathrm{~g}\left(\mathrm{NH}_{4}\right)_{2} \mathrm{Ce}(\mathrm{NO})_{6}$ in about $70 \mathrm{~mL}$ of $1 \mathrm{M} \mathrm{H}_{2} \mathrm{SO}_{4}$ and dilute to $100 \mathrm{~mL}$ with additional $1 \mathrm{M} \mathrm{H}_{2} \mathrm{SO}_{4}$.

6. Potassium permanganate, $0.1 \mathrm{~N}$. Dissolve $0.33 \mathrm{~g} \mathrm{KMnO}_{4}$ in $100 \mathrm{~mL}$ distilled water. Boil gently for 15 minutes, cool and filter through a plug of glass wool. Store in a brown glass bottle.

7. Orthophosphoric acid, $85 \%$. Test each lot before use:

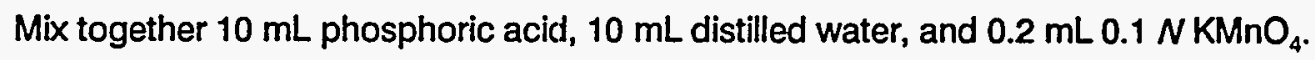
Heat to boiling on a hot plate, transfer to a steam bath, and let sit $10 \mathrm{~min}$. Reject lot if color disappears. 
8. Phosphoric acid reagent. Add $1 \mathrm{~mL} 0.4 \mathrm{~N}$ ceric sulfate (in $1 \mathrm{M} \mathrm{H}_{2} \mathrm{SO}_{4}$ ) to a $2.2 \mathrm{~L}$ bottle of phosphoric acid and mix.

9. Sulfamic acid, $1.5 \mathrm{M}$. Dissolve $146 \mathrm{~g} \mathrm{H}_{2} \mathrm{NSO}_{3} \mathrm{H}$ in about $900 \mathrm{~mL}$ distilled water and dilute to $1 \mathrm{~L}$. Filter.

10. Ferrous sulfate, $1 \mathrm{M}$. Add $10 \mathrm{~mL}$ concentrated $\mathrm{H}_{2} \mathrm{SO}_{4}$ to $75 \mathrm{~mL}$ distilled water. Add $28 \mathrm{~g} \mathrm{FeSO}_{4} \cdot 7 \mathrm{H}_{2} \mathrm{O}$, dissolve, cool, and dilute to $100 \mathrm{~mL}$. Prepare fresh every three days.

11. Nitric acid oxidizing reagent. Dissolve $1.0 \mathrm{~g}$ of ammonium molybdate [ $\left.\left(\mathrm{NH}_{4}\right)_{6} \mathrm{MO}_{7} \mathrm{O}_{24} \bullet 4 \mathrm{H}_{2} \mathrm{O}\right]$ in $100 \mathrm{~mL}$ distilled water. Add $125 \mathrm{~mL}$ concentrated nitric acid and $25 \mathrm{~mL} 1.5 \mathrm{M}$ sulfamic acid. Allow to cool to room temperature.

12. Sulfuric acid, $1 \%$. Add $20 \mathrm{~mL}$ concentrated sulfuric acid to $1980 \mathrm{~mL}$ distilled water and mix. Allow to cool to room temperature.

13. Vanadyl sulfate dihydrate. New lots may be verified for proper electrochemical response before use. Dissolve $3-4 \mathrm{~g}$ in distilled water and titrate with $0.027 \mathrm{~N}$ cerium(IV) titrant. Compare endpoint and slope of curve against that of a lot previously found satisfactory.

14. Vanadyl sulfate, $0.075 \%$. Dissolve $1.5 \mathrm{~g} \mathrm{VOSO}_{4} \bullet 2 \mathrm{H}_{2} \mathrm{O}$ in $2 \mathrm{~L} 1 \% \mathrm{H}_{2} \mathrm{SO}_{4}$. Prepare fresh daily.

D. Preparation of $0.027 \mathrm{~N}$ Cerium(IV) from Ceric Ammonium Nitrate

This procedure will prepare 5 liters of $0.027 \mathrm{~N} \mathrm{Ce}(\mathrm{IV})$ titrant solution. Other volumes may be prepared as desired.

1. Weigh $74 \mathrm{~g}$ ammonium ceric nitrate into a weighing boat, scoop, or paper.

2. Transfer to a 5-L volumetric flask and dissolve in about $4 \mathrm{~L} 1.0 \mathrm{M} \mathrm{H}_{2} \mathrm{SO}_{4}$.

3. Dilute to volume with $1.0 \mathrm{M} \mathrm{H}_{2} \mathrm{SO}_{4}$ and mix well. 
4. Stopper the fiask, place the flask on a lab bench and allow to sit for at least one month.

5. Carefully filter the top 4 liters of the solution into a second flask or bottle without disturbing the bottom portion which contains a fine sediment. Cap and mix well.

6. Store the decanted solution in tightly-capped glass bottles. Label with preparer's initials, dates prepared, and the notebook page where preparation is documented.

\section{PROCEDURE}

\section{A. Sample Preparation}

1. Dissolve samples by an approved NBL procedure. If no approved procedure exists, samples may be leached or dissolved by acid and/or fusion as the experience and knowledge of the analyst indicates, with supervisory approval.

2. Weigh aliquants of sample solution into clean $400-\mathrm{mL}$ beakers. Samples should contain between 20 and $45 \mathrm{mg}$ uranium.

3. Remove known and suspected chemical interferences. Most are removed by fuming; methods vary by chemical content.

a. "Known" standards. Fuming is not required, but may be done. If not fumed, evaporate to dryness on a steam bath.

b. "Blind" standards. Fuming is required if the associated samples are fumed. If not fumed, evaporate to dryness on a steam bath.

c. Samples containing calcium, aluminum, and other elements which form insoluble sulfates or oxides. Add $10 \mathrm{~mL}$ concentrated nitric acid and $5 \mathrm{~mL} 70 \%$ perchloric acid to the sample. Wash down beaker wall with distilled water and fume to dryness. A second fuming may be necessary to completely remove chloride or other halides. 
d. Samples containing organics. Add $10 \mathrm{~mL}$ concentrated nitric acid and $5 \mathrm{~mL}$ $9 M$ sulfuric acid. Wash down the beaker wall with distilled water and fume to dryness.

e. Other samples. Add $5 \mathrm{~mL} 9 \mathrm{M}$ sulfuric acid, $5 \mathrm{~mL}$ concentrated nitric acid and $1.5 \mathrm{~mL}$ perchloric acid. Wash down beaker wall with distilled water; fume to dryness.

4. If desired, a few drops of $8 \mathrm{MHNO}_{3}$ may be added to dry samples to ease later sample dissolution.

B. Blank Titration

1. Fill the polyethylene squeeze bottle with cerium(IV) titrant. Attach removable microtip. Weigh squeeze bottle with tip.

2. Wash down the wall of a clean $400-\mathrm{mL}$ beaker with $13-15 \mathrm{~mL}$ distilled water. Add a magnetic stirring bar.

3. Prepare blank for titration as described in this procedure for uranium titration, steps III.C.3 through III.C.9.

4. Record initial potential. If necessary, add titrant dropwise to an endpoint of 580-605 $\mathrm{mV}$. Record final potential.

5. Reweigh squeeze bottle with microtip. The loss in weight is the quantity of titrant used $\left(g T_{b}\right)$.

6. Repeat procedure. $g T_{b}$ for the second blank should agree well with the first blank with no indication of sluggish electrode response. Additionally, $g T_{b}$ should be less than $0.0060 \mathrm{~g}$ for both blanks. Do not proceed if these criteria have not been met.

C. Uranium Titration

1. Wet dry standards and sample aliquants with $3-5 \mathrm{~mL}$ distilled water and let sit for at least 15 minutes to dissolve the solid completely. 
2. Add a magnetic stirring bar and wash down beaker wall with distilled water to a total volume of 13-15 $\mathrm{mL}$. Do not exce€d $15 \mathrm{~mL}$.

NOTE: HF may be added to sample aliquants containing Si or Zr.

3. Add $40 \mathrm{~mL}$ phosphoric acid reagent (treated with $\mathrm{Ce}(\mathrm{IV})$ ); mix.

NOTE: Once the phosphoric acid has been added, the titration must be completed without interruption.

4. Add $5 \mathrm{~mL} 1.5 \mathrm{M}$ sulfamic acid around the rim, washing down beaker wall; mix.

5. Add $5 \mathrm{~mL} 1 \mathrm{M}$ ferrous sulfate directly into the titration mixture. Do not allow the reagent to splash on beaker wall. Mix 30 seconds.

6. Add $10 \mathrm{~mL}$ nitric acid oxidizing reagent around the rim of the beaker, washing down beaker wall; mix. A dark brown color will develop. Immediately after the color dissipates, start a timer set for three minutes. If sample does not change color, or if the color is a medium rather than dark brown, do not proceed.

7. Weigh or tare squeeze bottle with microtip. If necessary, wipe excess ceric titrant from the outside of the large tip and from inner attaching surface of microtip before weighing.

NOTE: Complete steps 8 through 11 within 5 minutes.

8. At the end of three minutes, add $100 \mathrm{~mL} 0.075 \%$ vanadyl sulfate or $100 \mathrm{~mL} 1 \%$ sulfuric acid then $75-125 \mathrm{mg} \mathrm{VOSC} \mathrm{C}_{4} \bullet 2 \mathrm{H}_{2} \mathrm{O}$, washing down beaker wall with liquid.

9. Insert electrodes and set $\mathrm{pH}$ meter to read absolute $\mathrm{mV}$. Set stirrer speed to create a vortex.

10. Remove microtip from titrant bottle and titrate with the large tip as rapidly as possible until the potential reaches approximately $480 \mathrm{mV}$.

11. Rinse down beaker walls with water. Place the microtip on the squeeze bottle and titrate to a potential endpoint of $580-605 \mathrm{mV}$. Record final potential. 
12. Reweigh squeeze bottle with microtip. The loss in weight is the quantity of titrant used $\left(g T_{u}\right)$.

\section{Standardization of Ceric Titrant}

1. Using the newly-prepared cerium(IV) solution, titrate at least ten "known" uranium standards, alternating titration of aliquants from each of two independently-prepared and verified lots. Use the titration method described above; perform opening and closing QC titrations with previously-standardized titrant. Repeat titrations for aliquants that were overtitrated or otherwise improperly assayed.

2. Enter mass of titrant used (in units of grams), and the mass of uranium expected (in units of $\mathrm{mg}$ ) for each titration into the "TITRANT FACTOR CALCULATION PROGRAM," accessed through the auxiliary menu on LIMS. Do not include results for aliquants that were overtitrated or otherwise improperly assayed.

The program will calculate a titrant equivalency factor for each titration, identify statistical outliers, and evaluate the precision of the data.

a. A mean titrant equivalency factor for normal uranium, $f_{n}$ (in units of $\mathrm{mg} \mathrm{U} / \mathrm{g}$ titrant), will be calculated from the data, excluding outliers, if:

(1) there is no more than one statistical outlier from each standard solution preparation,

(2) the standard deviations (sd's) of the factors, for each solution individually and as a combined set, excluding outliers, are less than $0.07 \%$, and

(3) the mean factors for the two solutions are statistically equivalent.

NOTE: If the titrations meet criteria 1 and 2, but a second round of titrations is requested because the titrations do not meet criterion 3 , consult your supervisor.

b. If the data do not meet the criteria in III.D.2.a, standardization must be repeated. 
E. Documentation Requirements

Include the date of assay, the number and issue date of this procedure, the balance and $\mathrm{pH}$ meter used, the titrant uranium equivalence factor and the notebook pages which document titrant standardization, and the room temperature.

1. For blank titration - record initial potential, $g$ titrant used, final potential, and time of titration.

2. For uranium titration - record NBL number and subsplit; sample preparation documentation; (if not included in preparation documentation, include) aliquant weight and dilution factor or reference value; final potential; $\mathbf{g}$ titrant used; time of titration; $\mathrm{mg} U$ calculated; and \%RD or assay result.

\section{CALCULATIONS}

A. Titrant Equivalency Factor for Normal Uranium, $\mathbf{f}_{n 2}$ in $\mathrm{mg} U / \mathrm{q}$ titrant

$$
f_{n}=\frac{m g U \text { expected }}{g \text { titrant used }}
$$

B. $\quad \mathrm{mg} U$ found $=\left(f_{n}\right)(E)\left(g T_{u}-g T_{b}\right)$

$$
\text { where } \quad \begin{array}{ll}
\mathrm{f}_{\mathrm{n}} & =\text { titrant equivalency factor for normal } \mathrm{U} \\
\mathrm{E} & =\text { sample enrichment factor } \\
& =\quad \text { (at. wt. of } \mathrm{U} \text { in sample) } /(238.029 \mathrm{~g} / \mathrm{mole}) \\
\mathrm{g} \mathrm{T}_{\mathrm{b}}=\mathrm{g} \text { titrant used in blank titration } \\
\mathrm{g} \mathrm{T}_{\mathrm{U}}=\mathrm{g} \text { titrant used in titration of uranium }
\end{array}
$$

C. $\& U=100 \times \frac{(m g \text { found })}{(1000)\left(s 0 I^{\prime} n \text { aliquant wt, g) (DF) }\right.}$

where DF = dilution factor

$=$ (g sample taken) $/$ (g sample sol'n prepared) 
D. $\quad \& R D=100 \times \frac{(m g U \text { found })-(m g U \text { known })}{(m g U \text { known })}$

\section{v. QUALITY ASSURANCE}

A. Measurement Control

At the beginning and end of each day of analysis, titrate a series of "known" and "blind" standards as described in Figure 1.

Acceptable results on a "known" standard confirms assay conditions are appropriate and good results are being obtained. Results (\%RD) must be within laboratory limits (to be determined) for the method.

Enter results for "blind" standards into the NBL computer-based QC program immediately after each titration. The program indicates whether the obtained value is within control limits. When out-of-control results are obtained, data may not be used. Stop analysis, correct the problem, and document its resolution before continuing. Unless a specific problem is noted (incorrect color change, overtitration, imprecise sample replicates, etc.), assurance from the NBL computer-based QC program that results are in control is the sole criterion for accepting assay data for this method. When out-of-control results are obtained,

\section{BEGIN:}

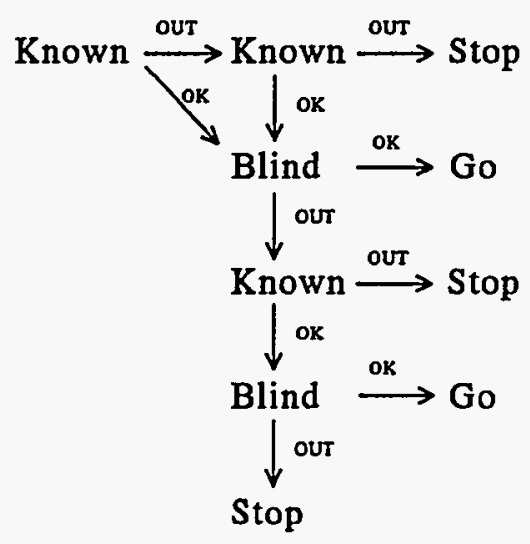

END:

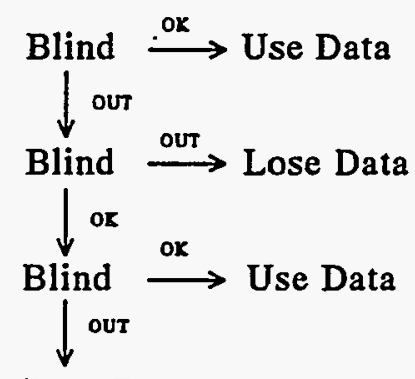

Lose Data

Figure 1. Measurement control assays. 
data may not be used. Stop analysis, report deficiency, correct the problem, and document its resolution before continuing.

\section{B. Sample Replicates}

Whenever possible, titrate samples in duplicate. Titrations should agree within $0.1 \%$ of the lower result. If they do not, an additional aliquant should be assayed. At least two of the three results must agree within $0.1 \%$. If they do not, the three results are discarded and the analysis repeated.

\section{TRAINING}

\section{A. Training Plan}

A new analyst shall be trained by a qualified analyst. This training shall include all related safety concerns and precautions. The qualified analyst shall provide the trainee with standardized cerium(IV) and aliquanted "known" standards. The qualified analyst shall demonstrate the titration technique and observe the trainee's technique. The trainee must practice the procedure until able to complete a minimum of ten titrations within one day with a relative standard deviation $\leq \pm 0.10 \%$ and a maximum of two outliers.

\section{B. Qualification Plan}

The new analyst must standardize titrant for use in qualification as described in this procedure. The new analyst shall then obtain at least twenty "blind" standards prepared for the quality control $(Q C)$ program. Twenty acceptable titrations must be performed over a period of not less than four days and not more than four weeks with not less than three and not more than five titrations per day.

The data shall be entered into the computer QC program at the end of each day. If the computer flags any entries as outliers, the new analyst shall immediately discuss the problem with the qualified analyst to determine the cause. An analyst is qualified when the mean of the results on twenty blind uranium sample titrations is within $\pm 0.05 \%$ of the reference (known) value with a relative standard deviation within $\pm 0.1 \%$.

The qualification information shall be entered on the form "Training DocumentationProficiency Testing", found in the NBL QA Manual. 


\section{Requalification Requirements}

If more than one year has elapsed since last assay of a "blind" standard by this method, the analyst must requalify by titration of five "blind" standards with no more than one outlier.

\section{SAMPLE STORAGE AND WASTE DISPOSAL}

A. Sample Storage

Samples may be aliquanted into $400-\mathrm{mL}$ beakers, reduced to less than $10 \mathrm{~mL}$, covered with watch glasses or petri dishes, and stored several years before use. Normally, aliquanted samples are not stored for longer than one year.

Samples in solution may be stored in plastic bottles; however, evaporation of water through the bottle can be expected. Bottles from which aliquants will be taken over long periods of time must be weighed after use and before reuse and the sample dilution factor corrected correspondingly.

B. Disposal

Wastes are minimized by preparation of only the amounts of reagents required.

This procedure generates uranium wastes which are to be collected in carboys for disposal as described in the NBL ES\&H Manual.

\section{REFERENCES}

A. Supporting

1. Procedure NBL-SA-U(E)-1, "Determination of Uranium by Ferrous Reduction in Phosphoric Acid and Titration with Dichromate (NBL Titrimetric Method)", current issue. 
2. L.Z. Bodnar, M.W. Lerner, and J.M. Scarborough, "The Effect of Impurities on the Now Brunswick Laboratory Titrimetric Method of Determining Uranium, " NBL-272, October 1974, pp. 5-8.

L.Z. Bodnar, "The Effect of High Acid Concentration on the Determination of Uranium at the 10-Milligram Level by the New Brunswick Laboratory Titrimetric Method," NBL272, October 1974, pp. 9-11.

L.Z. Bodnar, M.W. Lerner, and J.M. Scarborough, "Application of the New Brunswick Laboratory Method of Determining Uranium in Organic Extracts," NBL-272, October 1974, p.12.

L.Z. Bodnar and M.W. Lerner, "Ruggedness Testing of the New Brunswick Laboratory Titrimetric Method of Determining Uranium," NBL-272, October 1974, pp. 13-25.

L.Z. Bodnar and M.W. Lerner, "The Effect of Temperature and Temperature Control on the Accuracy of the New Brunswick Laboratory Titrimetric Method of Determining Uranium," NBL-272, October 1974, pp. 26-28.

3. "NBL Titrimetric Determination of Uranium,"

Section 9 of the New Brunswick Laboratory Safeguards Chemical Analysis Course, May 11-15, 1981.

\section{B. Suggested Reading}

1. H. A. Laitenen, Chemical Analysis, "Cerium(IV) as an Oxidant," McGraw-Hill Book Company, New York, NY, 1960, pp 378-392.

2. A.R. Eberle, M.W. Lerner, C.G. Goldbeck, and C.J. Rodden, "Titrimetric Determination of Uranium in Product, Fuel, and Scrap Materials After Ferrous lon Reduction in Phosphoric Acid. Part I. Manual Titration," NBL-252, July 1970.

3. W. Davies and W. Gray, Talanta, Vol. 11, 1964, p. 1203.

4. A.R. Eberle and M.W. Lerner, "Titrimetric Determination of Uranium at the 10 - and 20-Milligram Levels," NBL-258, June 1971, pp. 14-16. 
5. A.R. Eberle and M.W. Lerner, "Effect of Added Vanadyl Ion on the Accuracy of the New Brunswick Laboratory Titrimetric Method (Ferrous lon Reduction) of Determining Uranium," NBL-258, June 1971, pp. 22-25.

6. C.E. Pietri, J.S. Paller, and C.D. Bingham, "The Chemical and Isotopic Analysis of Uranium, Plutonium and Thorium in Nuclear Fuel Materials," presented at the American Nuclear Soclety Topical Meeting on May 15-17, 1978, Williamsburg, VA.

7. A.C. Zook, B.W. Moran, and L.H. Collins, "Application of a Weight Titration Technique to the NBL Titrimetric Method for Uranium (Including Temperature Effects Study)," NBL-293, March 1980, pp. 1-4.

8. S.G. Marathe, B.N. Patil, V. Bhandiwad, and K. Chander, "Studies on the Nature of the Reactions and Species Involved in Potentiometric Titrimetric Determination of Uranium," Talanta, Vol. 30, No. 3, 1983, pp. 151-154.

9. B.W. Moran, "The Effect of Procedural Variations on the NBL Gravimetric Titration for the Determination of Uranium," NBL-297, April 1981, pp. 5-9. 
Ames Laboratory

Ames, IA

ATTN: M. C. Edelson

Library

Argonne National Laboratory

Argonne, IL

ATTN: $\quad$ D. W. Green

R. B. Perry

Argonne National Laboratory

Idaho Falls, ID

ATTN: J. R. Krusul

Association Francaise de Normalisation

Paris, France

ATTN: J. C. Courtier 1

Babcock \& Wilcox Company

Lynchburg, VA

ATTN: Information Services

1

Battelle Memorial Institute

Pacific Northwest Laboratory

Richland, WA

ATTN: Technical Information Section

Bendix Kansas City Division

Kansas City, MO

ATTN: L. Stratton

1

British Nuclear Fuels Ltd.

Capenhurst Works, United Kingdom

ATTN: Library

British Nuclear Fuels Ltd.

Springfield Works, United Kingdom

ATTN: Library

British Nuclear Fuels Ltd.

Windscale \& Calder Works, United Kingdom

ATTN: Library

I. McGowan

2

Brookhaven National Laboratory

Upton, NY

ATTN: Research Library

Reference Section

J. Indusi

A. Reisman (ISPO) 
Bundesanstalt fur Materialprufung

Berlin, Federal Republic of Germany

ATTN: T. Tamberg

CEC-JRC Geel

Institute for Reference Materials and Measurements

Geel, Belgium
ATTN:
P. DeBievre
K. Meyer

CEC-JRC Karlsruhe

Institute fur Transurane

Karlsruhe, Federal Republic Germany

ATTN: W. Bartscher

CEC-JRC Ispra

Ispra, Italy

ATTN: M. Cuypers

COGEMA

Center de la Hague

Cherbourg, France

ATTN: Mme. Baude

COGEMA

Establissment de Pierrelatte

Pierrelatte, France

ATTN: R. Picard

Comitato Nazionale per l'Energia Nucleare

Rome, Italy

ATTN: A. Moccia

V. Pagliai

Commissariat a l'Energie Atomique

Grenoble, France

ATTN: L. Chaussabel

J. Dettwiller

General Atomic Company

San Diego, CA

ATTN: Library

Gessellschaft zur Wiederaufarbeitung von Kernbrennstoffen mbH

Eggenstein-Leopoldshafen

Federal Republic of Germany

ATTN: R. Berg

International Atomic Energy Agency

Safeguards Analytical Laboratory

Seibersdorf, Austria

ATTN: S. Deron

G. Bagliano 
International Atomic Energy Agency

Vienna, Austria

ATTN: E Kuhn

1

Kernforschungszentrum Karlsruhe $\mathrm{GmbH}$

Karlsruhe, Federal Republic of Germany

ATTN: Library

Lawrence Livermore National Laboratory

Livermore, CA

ATTN: W. Ruhter

Los Alamos National Laboratory

Los Alamos, NM

\section{ATTN: J. Phillips \\ J. Tape \\ D. J. Temer}

Report Librarian

Martin Marietta Energy Systems, Inc.

Oak Ridge National Laboratory

Oak Ridge, TN

ATTN: J. Wade

M. Poutsma

Martin Marietta Energy Systems, Inc.

Y-12 Plant

Oak Ridge, TN

ATTN: J. Dorsey

Monsanto Research Corporation

Miamisburg, $\mathrm{OH}$
ATTN: R. Goss
R. Seiler
Library

Westinghouse Materials Co. of Ohio Cincinnati, $\mathrm{OH}$

ATTN: Library

Nuclear Fuel Services

Erwin, TN

ATTN: Library

Nuclear Material Control Center

Safeguards Analytical Laboratory

Japan

ATTN: K. Iwamoto

Reaktor Brennelement Union GmbH

Hanau, Federal Republic of Germany

ATTN: R. Saiger 
Westinghouse Hanford Operations

Richland, WA

$\begin{array}{ll}\text { ATTN: } & \text { B. Baird } \\ & \text { H. Meznarich } \\ \text { A. E. Schilling }\end{array}$

Rockwell International

Rocketdyne Division

Canoga Park, CA

ATTN: Library

EG\&G

Rocky Flats Plant

Golden, CO

ATTN: J. Weiss

Library

2

Sandia National Laboratories

Albuquerque, NM

ATTN: D. Miyoshi

1

Studiecentrum voor Kernenergie

Centre d'Etude de l'Energie Nucleaire

Mol, Belgium

ATTN: P. DeRegge

1

United Kingdom Atomic Energy Authority

Atomic Energy Research Establishment

Hanwell, United Kingdom

ATTN: D. Crossley

United Kingdom Atomic Energy Authority

Dounreay Nuclear Power Development Establishment

United Kingdom

ATTN: J. L. Drummond

STRUGHOLD (TSK) Aero Medical Library

USAF School of Aerospace Medicine

Brooks AFB, TX

ATTN: Documents Librarian

U.S. Department of Energy

Washington, D.C.

ATTN: DOE Library

U.S. Department of Energy

Office of Safeguards and Security

Washington, D.C.

ATTN: E. J. McCallum

O. B. Johnson

B. Todd

D. W. Crawford

G. D. Smith 
U.S. Department of Energy Albuquerque Operations Office

Albuquerque, NM

ATTN: L. Muller

U.S. Department of Energy Chicago Operations Office Argonne, IL
ATTN: T. Gradle
C. Pietri
J. Huagen
R. Lang

4

U.S. Department of Energy Idaho Operations Office Idaho Falls, ID

ATTN: B. Green

U.S. Department of Energy New Brunswick Laboratory Argonne, IL

ATTN: H. R. Martin

K. Lewis

R. D. Oldham

W. G. Mitchell

M. M. Lachman

5

U.S. Department of Energy

Oak Ridge, TN

ATTN: Technical Information Center

U.S. Department of Energy Oak Ridge Operations Office Oak Ridge, TN

ATTN: R. Green

G. Proco

U.S. Department of Energy Pittsburgh Energy Technology Center Pittsburgh, PA

ATTN: Technical Library

U.S. Department of Energy Richland Operations Office Richland, WA

ATTN: J. Spracklen

U.S. Department of Energy

Rocky Flats

Golden, CO

ATTN: B. Reece

1 
U.S. Department of Energy

Oakland Operations Office

Oakland, CA

ATTN: J. Turner

D. Wilhem

U.S. Department of Energy

Savannah River Operations Office

Aiken, SC

ATTN: T. Williams

U.S. Department of Energy

Schnectady Naval Reactors Office

Schnectady, NY

ATTN: B. M. Erickson

U.S. Environmental Protection Agency

Las Vegas, NV

ATTN: Director

U.S. Nuclear Regulatory Commission

Region II

Atlanta, GA

ATTN: E. McAlpine

U.S. Nuclear Regulatory Commission

Region III

Glen Ellyn, IL

$$
\text { ATTN: L. Creed }
$$

U.S. Nuclear Regulatory Commission

Region V

Walnut Creek, CA

ATTN: J. Montgomery

Westinghouse Electric Corporation

West Mifflin, PA

ATTN: Librarian

Westinghouse Hanford Company

Richland, WA

ATTN: Document Control

Westinghouse Idaho Nuclear Company

Idaho Falls, ID

ATTN: Technical Library

Westinghouse Savannah River Co.

Savannah River Site

Aiken, SC

ATTN: P.T. Deason, Jr.
A. Gibbs
M. K. Holland
W. A. Spencer
Technical Library 